$\left.\mathrm{CO}^{+}, 53\right), 77\left(\mathrm{C}_{6} \mathrm{H}_{5}{ }^{+}, 60\right), 73$ ( $\left.\mathrm{TMSi}^{+}, 84\right) ;$ 6-methyl-4-hydroxy-2-pyrone: $\mathrm{RR}_{\mathrm{t}}$ $0.35,198\left(\mathrm{M}^{+}, 18\right), 183\left([\mathrm{M}-\mathrm{Me}]^{+}, 16\right), 170\left([\mathrm{M}-\mathrm{CO}]^{+}, 54\right), 155\left([\mathrm{M}-\mathrm{CO}-\mathrm{Me}]^{+}\right.$, 15), $139\left(\left[\mathrm{M}-\mathrm{Me}-\mathrm{CO}_{2}\right]^{+}, 10\right), 127\left([\mathrm{M}-\mathrm{Me}-2 \mathrm{CO}]^{+}, 13\right), 99$ (12), 84 (13), 73 $\left(\mathrm{TMSi}^{+}, 100\right), 43\left(\mathrm{CH}_{3} \mathrm{CO}^{+}, 55\right)$. The numbers show $\mathrm{m} / z$ values, and the key fragments and their relative intensities are indicated in parentheses.

Received 4 August; accepted 14 October 1998.

1. Helariutta, Y. et al. Chalcone synthase-like genes active during corolla development are differentially expressed and encode enzymes with different catalytic properties in Gerbera hybrida (Asteraceae) Plant Mol. Biol. 28, 47-60 (1995).

2. Helariutta, Y. et al. Duplication and functional divergence in the chalcone synthase gene family of Asteraceae: evolution with substrate change and catalytic simplification. Proc. Natl Acad. Sci. USA 93, 9033-9038 (1996)

Thaisrivongs, S. et al. Structure-based design of HIV protease inhibitors: 5,6-dihydro-4-hydroxy-2pyrones as effective, nonpeptidic inhibitors. I. Med. Chem. 39, 4630-4642 (1996).

4. Hagen, S. E. et al. Synthesis of 5,6-dihydro-4-hydroxy-2-pyrones as HIV-1 protease inhibitors: the profound effect of polarity on antiviral activity. J. Med. Chem. 40, 3707-3711 (1997).

5. Tait, B. D. et al. 4-hydroxy-5,6-dihydropyrones. 2. Potent non-peptide inhibitors of HIV protease J. Med. Chem. 40, 3781-3792 (1997).

6. Schröder, J. A family of plant-specific polyketide synthases: facts and predictions. Trends Plant Sci. 2, 373-378 (1997)

7. Elomaa, P., Helariutta, Y., Kotilainen, M. \& Teeri, T. H. Transformation of antisense constructs of the chalcone synthase gene superfamily into Gerbera hybrida: differential effect on the expression of family members. Mol. Breed. 2, 41-50 (1996).

8. Nagumo, S., Toyonaga, T., Inoue, T. \& Nagai, M. New glucosides of a 4-hydroxy-5-methylcoumarin and a dihydro- $\alpha$-pyrone from Gerbera Jamesonii hybrida. Chem. Pharm. Bull. (Tokyo) 37, 2621-2623 (1989).

9. Cardellina, J. G. II \& Meinwald, J. Isolation of parasorbic acid from the cranberry plant, Vaccinum macrocarpon. Phytochemistry 19, 2199-2200 (1980).

10. Numata, A. et al. Plant constituents biologically active to insects. VI. Antifeedants for larvae of the yellow butterfly Eurema hecabe mandarina in Osmunda japonica. Chem. Pharm. Bull. (Tokyo) 38, 2862-2865 (1990)

11. Tschesche, R., Hoppe, H.-J., Snatzke, G., Wulff, G. \& Fehlhaber, H.-W. Über Parasorbosid, den glykosidischen Vorläufer der Parasorbinsäure, aus Vogelbeeren. Chem. Ber. 104, 1420-1428 (1971).

12. Pyysalo, H. \& Kuusi, T. Phenolic compounds from the berries of mountain ash, Sorbus aucuparia. J. Food Sci. 34, 636-638 (1974)

13. Buston, H. W. \& Roy, S. K. The physiological activity of some simple unsaturated lactones. I. Effect on the growth of certain microorganisms. Arch. Biochem. 22, 1-7 (1949).

14. Kuhn, R., Jerchel, D., Moewus, F., Möller, E. F. \& Lettré, H. Über die chemische Natur der Blastokolin und ihre Einwirkung auf keimende Samen, Pollenkörner, Hefen, Bacterien, Epithelgewebe und Fibroblasten. Naturwissenschaften 37, 463 (1943)

15. Oster, U., Blos, I. \& Rüdiger, W. Natural inhibitors of germination and growth. IV. Compounds from fruit and seeds of mountain ash (Sorbus aucuparia). Z. Naturforsch. 42c, 1179-1184 (1987).

16. Moewus, F. \& Schader, E. Die Wirkung von Cumarin und Parasorbinsäure auf das Austreiben von Kartoffelknollen. Z. Naturforsch. 6b, 112-115 (1951)

17. Yalpani, M., Willecke, K. \& Lynen, F. Triacetic acid lactone, a derailment product of fatty acid biosynthesis. Eur. J. Biochem. 8, 495-502 (1969).

18. Dimroth, P., Walter, H. \& Lynen, F. Biosynthese von 6-Methylsalicylsäure. Eur. J. Biochem. 13, 98-110 (1970).

19. Kurosaki, F., Kizawa, Y. \& Nishi, A. Derailment product in NADPH-dependent synthesis of a dihydroisocoumarin 6-hydroxymellein by elicitor-treated carrot cell extracts. Eur. J. Biochem. 185, 85-89 (1989).

20. Pieper, R., Luo, G., Cane, D. E. \& Khosla, C. Cell-free synthesis of polyketides by recombinant erythromycin polyketide synthases. Nature 378, 263-266 (1995).

21. Dimroth, P., Ringelmann, E. \& Lynen, F. 6-Methylsalicylic acid synthetase from Penicillium patulum. Some catalytic properties of the enzyme and its relation to fatty acid synthetase. Eur. J. Biochem. 68 591-596 (1976).

22. McInnes, A. G., Yoshida, S. \& Towers, G. H. N. A phenolic glycoside from Psilotum nudum (L) Griseb. Tetrahedron 21, 2939-2946 (1965)

23. Schüz, R., Heller, W. \& Hahlbrock, K. Substrate specificity of chalcone synthase from Petroselinum hortense. Formation of phloroglucinol derivates from aliphatic substrates. J. Biol. Chem. 258, 6730$6734(1983)$.

24. Zuurbier, K. W. M. et al. 4-Hydroxy-2-pyrone formation by chalcone and stilbene synthase with nonphysiological substrates. Phytochemistry (in the press).

25. Kreuzaler, F., Light, R. J. \& Hahlbrock, K. Flavanone synthase catalyzes $\mathrm{CO}_{2}$ exchange and decarboxylation of malonyl-CoA. FEBS Lett. 94, 175-178 (1978).

26. Tropf, S., Lanz, T., Rensing, S. A., Schröder, J. \& Schröder, G. Evidence that stilbene synthases have developed from chalcone synthases several times in the course of evolution. J. Mol. Evol. 38, 610-618 (1994).

27. Schenk, P. M., Baumann, S., Mattes, R. \& Steinbiss, H.-H. Improved high-level expression system fo eucaryotic genes in Escherichia coli using T7 RNA polymerase and rare tRNAs. Biotechniques 19, 196 200 (1995)

28. Lanz, T., Tropf, S., Marner, F.-J., Schröder, J. \& Schröder, G. The role of cysteines in polyketide synthases: site-directed mutagenesis of resveratrol and chalcone synthases, two key enzymes in different plant-specific pathways. J. Biol. Chem. 266, 9971-9976 (1991).

Acknowledgements. We thank T. J. Simpson for a sample of authentic 6-methyl-4-hydroxy-2-pyrone L. Britsch for Fractogel EMD Butyl 650 S, and R. Mattes for E. coli strain RM82 with plasmid pUBS520. The group in Freiburg was supported by a grant from the Deutsche Forschungsgemeinschaft. T.H.T. and
P.P. thank the Academy of Finland and the Deutsche Forschungsgemeinschaft, respectively, for financial support.

Correspondence and requests for materials should be addressed to J.S. (e-mail: jschroe@ruf.unifreiburg.de)

\section{erratum}

\section{Crystal structure of the complex of the cyclin D-dependent kinase Cdk6 bound to the cell-cycle inhibitor p19 ${ }^{\text {INK4d }}$}

Deborah H. Brotherton, Venugopal Dhanaraj, Scott Wick, Leonardo Brizuela, Peter J. Domaille, Elena Volyanik, Xu Xu, Emilio Parisini, Brian O. Smith, Sharon J. Archer, Manuel Serrano, Stephen L. Brenner, Tom L. Blundell \& Ernest D. Laue

Nature 395, 244-250 (1998)

In the text we refer to the work of Batchelor et al. (ref. 25) on the structure of a GABP $\alpha / \beta-D N A$ complex, but GABP was incorrectly written as $\operatorname{GABA}(\gamma$-aminobutyric acid).

In addition, some spurious dark patches were introduced into Fig. 1 during the production process but these do not affect the information conveyed by the figure.

\section{retraction}

\section{Identification and role of adenylyl cyclase in auxin signalling in higher plants}

Takanari Ichikawa, Yoshihito Suzuki, Inge Czaja, Carla Schommer, Angela Leßnick, Jeff Schell

\& Richard Walden

Nature 390, 698-701 (1997)

Some of the results reported in this Letter cannot be reproduced. We know that the data on protoplast division described for Figs 1a, c, $2 \mathrm{a}, \mathrm{b}$ and 4 , and the corresponding experimental procedures described in the Methods section and the text, are wrong. In fact, the data showing that cAMP can stimulate protoplast division in the absence of auxins are not correct. Hence, we need to retract this paper. We apologize for any misunderstanding that this might have caused.

Note from the Editor: One author, R.W., although concerned with the accuracy of parts of this paper, reserves judgement concerning its retraction and awaits the outcome of further experimentation. 


\title{
Crystal structure of the complex of the cyclin D-dependent kinase Cdk6 bound to the cell-cycle inhibitor p19 ${ }^{\text {INK4d }}$
}

\author{
Deborah H. Brotherton ${ }^{\star}$, Venugopal Dhanaraj ${ }^{\star}$, Scott Wick $\dagger$, Leonardo Brizuela $\dagger$, Peter J. Domaille $\ddagger$, Elena \\ Volyanik $^{\star}$, Xu Xu†, Emilio Parisini ${ }^{\star}$, Brian O. Smith ${ }^{\star}$, Sharon J. Archer $\ddagger$, Manuel Serrano\$, Stephen L. Brenner \\ Tom L. Blundell* \& Ernest D. Laue ${ }^{\star}$ \\ * Cambridge Centre for Molecular Recognition, Department of Biochemistry, University of Cambridge, 80 Tennis Court Road, Cambridge CB2 1GA, UK \\ $\dagger$ Mitotix Inc., One Kendall Square, Building 600, Cambridge, Massachusetts 02139, USA \\ $\ddagger$ Du Pont Pharmaceutical Company, Box 80353, Wilmington, Delaware 19880-0353, USA \\ $\S$ Department of Immunology and Oncology, Centro Nacional de Biotecnologia, Campus de Cantoblanco, Madrid E-28049, Spain
}

The crystal structure of the cyclin D-dependent kinase Cdk6 bound to the p $19^{\text {INK4d }}$ protein has been determined at $1.9 \AA$ resolution. The results provide the first structural information for a cyclin D-dependent protein kinase and show how the INK4 family of CDK inhibitors bind. The structure indicates that the conformational changes induced by $p 19^{\text {INK4d }}$ inhibit both productive binding of ATP and the cyclin-induced rearrangement of the kinase from an inactive to an active

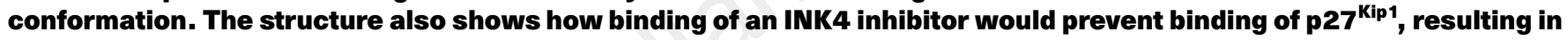
its redistribution to other CDKs. Identification of the critical residues involved in the interaction explains how mutations in Cdk4 and p16 ${ }^{\mathrm{INK} 4 \mathrm{a}}$ result in loss of kinase inhibition and cancer.

Cyclin-dependent kinases (CDKs) are important in controlling the eukaryotic cell cycle. CDKs are switched on and off at different times; Cdc2/cyclin B regulates entry and exit from mitosis, whereas the cyclin D-dependent kinases (Cdk4/cyclin D and Cdk6/cyclin D) and those of Cdk2 (Cdk2/cyclin E and Cdk2/cyclin A) regulate G1 progression and entry into the $S$ phase of the cell cycle ${ }^{1}$.

CDKs are partially activated by their regulatory cyclin subunits, which are periodically synthesized and degraded during the cell cycle. The cyclin/CDK complex is fully activated by phosphorylation of a threonine residue in the T-loop by CDK-activating kinase $(\mathrm{CAK})^{2}$. In addition, phosphorylation of tyrosine and/or threonine residue(s) in the phosphate-binding loop by Weel and Myt1 inhibits $\mathrm{CDKs}^{3}$. This inhibition can be reversed by the dualspecificity Cdc25 phosphatases ${ }^{4}$.

CDKs are further regulated by CDK inhibitors (CDKIs), which induce cell-cycle arrest in response to different signals ${ }^{5,6}$. In

\begin{tabular}{lcc}
\hline \multicolumn{2}{l}{ Table 1 Data collection and statistics from the crystallographic analysis } \\
\hline Data set & Native & Native \\
Resolution $(\AA)$ & $15.0-2.1$ & $18.54-1.90$ \\
Observations & 326,706 & 166,218 \\
Unique reflections & 31,989 & 41,965 \\
Data coverage (\%) & 97.8 & 98.5 \\
$R$ sym (\%) & 9.6 & 5.4 \\
Refinement & & \\
Resolution range $(\AA)$ & & $18.54-1.90$ \\
$R$-factor/Free $R$-factor & & $20.0 / 25.3$ \\
(all data) & & \\
Number of atoms & & 3,830 \\
Number of waters & & 286 \\
R.m.s.d. bond lengths $(\AA)^{*}$ & 0.024 \\
R.m.s.d. bond angles $(\mathrm{deg})^{*}$ & 2.3 \\
R.m.s.d. B-factors* & & $1.8 / 3.3$ \\
backbone/side chain $\left(\AA^{2}\right)$ & &
\end{tabular}

backbone/side chain $\left(\AA^{2}\right)$

$R_{\text {sym }}=\Sigma_{h} \Sigma_{i} I_{h j}-I_{h} \mid / \Sigma_{h} \Sigma_{i} I_{h}$ for the intensity $(/)$ of $i$ observations of reflection $h$

$R$ - factor $=\Sigma\left|F_{0}-F_{\mathrm{C}}\right| \Sigma\left|F_{\mathrm{O}}\right|$, where $F_{\mathrm{O}}$ and $F_{\mathrm{C}}$ are the observed and calculated structure factors, respectively.

* The r.m.s. deviations from ideal geometry and r.m.s. variation in the B-factors of bonded atoms. proliferating cells, their redistribution between the different complexes coordinates the timing of activation of the different $\mathrm{CDKs}^{7,8}$. Two classes of CDKI have been identified. First, the Cip/Kip family members, which include $\mathrm{p} 21^{\mathrm{Cip} 1, \mathrm{WAF}-1}, \mathrm{p} 27^{\mathrm{Kip} 1}$ and $\mathrm{p} 57^{\mathrm{Kip} 2}$, inhibit all G1- and S-phase CDKs and are important in p53- and TGF 3 mediated cell-cycle arrest ${ }^{5}$. Second, the INK4 family, which is specific for Cdk4 and Cdk6 (ref. 9), has four known family members, p16 ${ }^{\mathrm{INK} 4 \mathrm{a}}, \mathrm{p} 15^{\mathrm{INK} 4 \mathrm{~b}}, \mathrm{p} 18^{\mathrm{INK} 4 \mathrm{c}}$ and $\mathrm{p} 19^{\mathrm{INK} 4 \mathrm{~d}}$ (refs 9-13). These bind in the absence or presence of cyclin $\mathrm{D}$, but show different patterns of expression ${ }^{6}$. Their interactions with Cdk4 and Cdk6 regulate phosphorylation of the retinoblastoma protein ( $\mathrm{pRB})$, which leads to disruption of $\mathrm{pRB} / \mathrm{E} 2 \mathrm{~F}$ complexes and activation of S-phase genes ${ }^{14}$. Changes in expression or mutations to cyclin D1, to $\mathrm{Cdk} 4$, to $\mathrm{p} 16^{\mathrm{INK} 4 \mathrm{a}}$ and to $\mathrm{pRB}$ are all strongly implicated in cancer ${ }^{1}$.

To help understand the regulation of cyclin D-dependent kinases, we have determined the three-dimensional structure of the p $19^{\text {INK4d }} /$ Cdk6 complex by X-ray diffraction analysis (Fig. 1 and Table 1).

\section{Overall structure of the complex}

Cdk6, in common with other kinases, consists of two domains with the catalytic cleft lying between the two. The overall structure of Cdk6 is very similar to that of Cdk2 (refs 15-17). The aminoterminal domain (residues 5-100) comprises a five-stranded $\beta$ sheet that packs against the PLSTIRE helix $\alpha 1$ (PSTAIRE in Cdk2). The cyclin interacts with helix $\alpha 1$, whose conformation switches to activate the kinase $\mathrm{e}^{16,17}$. The larger carboxy-terminal domain (residues 101-309) is mainly $\alpha$-helical, with a small $\beta$-sheet (Fig. 2).

$\mathrm{p} 19^{\mathrm{INK} 4 \mathrm{~d}}$ comprises five ankyrin repeats ${ }^{18}(\mathrm{I}-\mathrm{V})$, each consisting of an extended strand followed by a helix-loop-helix (HLH) motif and another extended strand. Consecutive repeats are linked by a series of $\beta$-turns between the $\mathrm{N}$ and $\mathrm{C}$ termini. The antiparallel helices in each repeat stack together, giving the protein an elongated L-shaped structure (Fig. 2). The four helical bundles form the long 
arm of the $L$, whereas the extended strands and $\beta$-turns form its base $^{19-21}$ (Fig. 2b).

p $19^{\text {INK4d }}$ binds through its concave face to the cleft between the Nand C-terminal domains of Cdk6, just to one side of the active site (Fig. 2). In p19 ${ }^{\mathrm{INK} 4 \mathrm{~d}}$, the unusual ankyrin $\mathrm{II}^{19-21}$ is at the centre of the interface which mainly involves ankyrins I-III (Fig. 3a, b). In Cdk6, the interaction occurs mainly through the $\beta$-sheet in the $\mathrm{N}$-terminal domain, loop $\mathrm{L} 7$ linking the $\mathrm{N}$ - and $\mathrm{C}$-terminal domains, and helix $\alpha 2$ in the C-terminal domain (Fig. 3a, c). As predicted ${ }^{19}$, the structure shows that INK4 protein binding does not obstruct the cyclin binding site, which is consistent with the formation of ternary complexes with cyclin D/Cdk6 (refs 11, 22) (D.H.B., S.W., L.B. and E.D.L., unpublished results).

\section{Structure of the $p 19^{\text {INK4d }} /$ Cdk6 interface}

The interface consists of three main parts. In the first, helices $\alpha 1, \alpha 3$ and $\alpha 5$ of $\mathrm{p} 19^{\mathrm{INK} 4 \mathrm{~d}}$ pack almost at right angles across the N-terminal $\beta$-sheet of Cdk6 (Figs 2 and 4). In the second, the $\beta$-turns between ankyrins I/II and II/III in p19 ${ }^{\mathrm{INK} 4 \mathrm{~d}}$ provide a lid over the $\beta$-sheet of Cdk6. Together, these interactions form a clamp around the $\mathrm{N}$ terminal $\beta$-sheet of Cdk6 (Fig. 2b). Finally, loops L4 and L6, between the helices in ankyrins II and III of $19^{\text {INK4d }}$, respectively, clamp down on the C-terminal domain, moving the N-terminal domain relative to that of the $\mathrm{C}$ terminus. Loop L4 of p19 $9^{\text {INK4d }}$ binds over the linker (Cdk6 loop L7), with the side chain of Met 50 to one side and Gly 52 to the other. Loop L6, in particular Phe 86, binds in a hydrophobic pocket between loops L7 and loop L11 in the C-

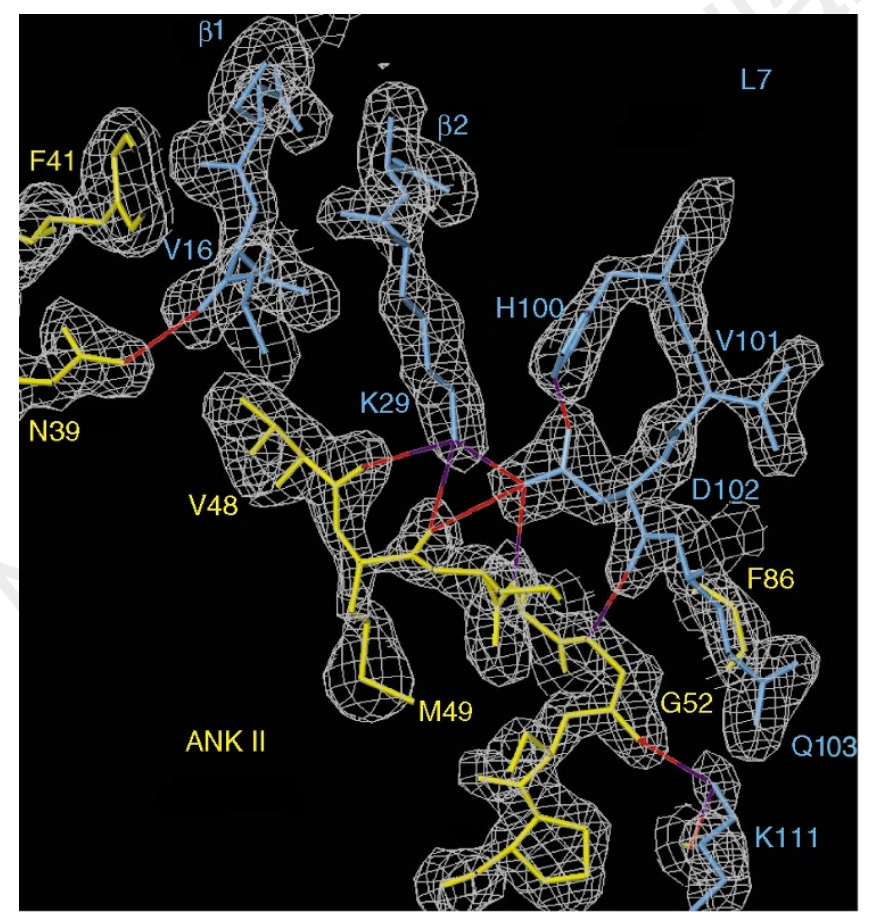

Figure 1 Electron density at the $\mathrm{p} 19^{\mathrm{INK} 4 \mathrm{~d}} / \mathrm{Cdk} 6$ interface contoured at $1.2 \sigma . \mathrm{p} 19^{\mathrm{INK} 4 \mathrm{~d}}$ and Cdk6 are coloured yellow and blue, respectively. Lys 29 and Asp 102, which form an ion pair in Cdk6, and residues in p19 ${ }^{\text {INK4d }}$ involved in intermolecular hydrogen bonding, are labelled. Hydrogen bonds, in blue/red, are formed between: the carbonyl groups of Val 48 and Met 49 (p19 $\left.{ }^{\text {INK4d }}\right)$ and the side chain of Lys 29 (Cdk6); the carbonyl of Met 49 and amide of Phe $51\left(p 19^{\text {INK4d }}\right)$ with the side chain of Asp 102 (Cdk6); the amide of Gly 52 (p19 ${ }^{\text {INK4d }}$ ) with the carbonyl of Asp 102 (Cdk6); and the carbonyl of Gly 52 (p19 ${ }^{\text {INK4d }}$ ) with the side chain of Lys 111 (Cdk6). The $\left(2\left|F_{\mathrm{O}}\right|-\left|F_{\mathrm{C}}\right|\right)$-simulated annealing omit map, in grey, was calculated at $1.9 \AA$ using phases from a model in which all atoms from residues 98 to 104 in Cdk6 were omitted together with all those within the surrounding $5 \AA$. The model was subjected to refinement by slow cooling from 2,500 K using X-PLOR ${ }^{43}$. Figures 1 and $5 \mathrm{c}$ were produced using the computer program $\mathrm{O}^{46}$. terminal domain of Cdk6 (Figs $2 \mathrm{a}$ and 4). The total surface area buried in the complex is $1,700 \AA^{2}$ (Fig. 3a).

The interaction between $\mathrm{p} 19^{\mathrm{INK} 4 \mathrm{~d}}$ and Cdk6 partly buries several intermolecular ion pairs (Fig. 4). Apart from Arg 40 in p19 ${ }^{\text {INK4d }}$ (Ser in $\mathrm{p} 16^{\mathrm{INK} 4 \mathrm{a}}$ and Gly in $\left.\mathrm{p} 18^{\mathrm{INK} 4 \mathrm{c}}\right)$, appropriate positively or negatively charged groups are conserved between Cdk4 and Cdk6, but only Arg 31 is conserved between Cdk4/6 and Cdk2. In Cdk2, positions 14, 18 and 111 are Gln, Lys and Ala (Fig. 3c), which suggests that specificity of the INK4 proteins for Cdk4 and Cdk6 results in part from their inability to form complementary electrostatic surfaces with other CDKs. The unusual ankyrin II (refs 19-21) forms a network of intermolecular hydrogen bonds to the Cdk6 Lys 29Asp 102 ion pair that is buried by the interaction (Figs 1 and 4). These interactions should also be conserved in Cdk4, but not in Cdk2, where His 100-Asp 102 is replaced by Phe $82-$ His 84 (Fig. $3 \mathrm{c}$ ); replacement of residues 100-102 with those from Cdk2 abolishes the ability of $\mathrm{p} 16^{\mathrm{INK} 4 \mathrm{a}}$ to inhibit the kinase (M.S., unpublished results).

His 119 , the most C-terminal residue of $\mathrm{p} 19^{\mathrm{INK} 4 \mathrm{~d}}$ that interacts with Cdk6, packs to one side of loop L11 (Fig. 4a). This indicates that the shorter INK4 proteins (for example, $\mathrm{p} 15^{\text {INK4b }}$ ) will all make very similar interactions with $\mathrm{Cdk} 4 / \mathrm{Cdk} 6$; the existence of active p $16^{\text {INK4a }}$ mutants with C-terminal deletions supports this conclusion $^{23}$.

Two other structures of ankyrin repeat-domain complexes are known. 53BP2 interacts with p53 through the convex face of its Lshaped structure, on the other side of the $\beta$-turns to $\mathrm{p} 19^{\mathrm{INK} 4 \mathrm{~d}} / \mathrm{Cdk} 6$ (ref. 24). The interaction between the $\alpha$ - and $\beta$-subunits in the GABA ( $\gamma$-aminobutyric acid) $\alpha / \beta$-DNA complex is more similar to that of $\mathrm{p} 19^{\mathrm{INK} 4 \mathrm{~d}} / \mathrm{Cdk} 6$. The $\beta$-ankyrin repeat domain interacts with the $\alpha$-subunit through its concave face, but this involves mainly the tips of the four $\beta$-turns in a more hydrophobic interface $e^{25}$.

Analysis of mutations to $\mathrm{p}^{\text {INK4a }}$. The structure allows us to identify $\mathrm{p} 16^{\mathrm{INK} 4 \mathrm{a}}$ mutations that affect interactions with Cdk4 and Cdk6, as opposed to destabilizing its structure ${ }^{19-21,26}$. For example, four mutations found in $\mathrm{p} 16^{\mathrm{INK} 4 \mathrm{a}}$ associated with inherited melanomas are equivalent to residues in p19 ${ }^{\text {INK4d }}$ involved in the interaction with Cdk6: Gln 47 to Arg, Met 50 to Ile, Arg 83 to Pro and Asp 104 to Asn (p19 numbering; Figs 3a, b). Of these, Met 50 and Arg 83 become completely buried on complex formation (Fig. $3 a)$; Met 50 packs alongside loop L7 and the beginning of helix $\alpha 2$ in Cdk6, whereas Arg 83 tucks into a pocket near the top of Cdk6 strand $\beta 3$, making many interactions (Fig. 4a). The structure allows a complete analysis of all known mutations to $\mathrm{p} 16^{\mathrm{INK} 4 \mathrm{a}}$.

Analysis of mutations to Cdk4. Both of the known cancer-associated mutations in $\mathrm{Cdk} 4$ are to charged residues in the interface that are directly involved in $\mathrm{p} 19^{\mathrm{INK} 4 \mathrm{~d}} / \mathrm{Cdk} 6$ interactions (see above and Fig. 3a, c). Mutation of Arg 24 in Cdk4 (Arg 31 in Cdk6) affects the ability of p $16^{\text {INK4a }}$ to inhibit the kinase $e^{27,28}$ and is strongly linked to sporadic and hereditary melanomas ${ }^{27,29-31}$. Mutation of Lys 22 to Ala in Cdk4 (Lys 29 in Cdk6) also affects the ability of p16 ${ }^{\text {INK4a }}$ to inhibit the kinase $\mathrm{e}^{28}$ (M.S., unpublished results) and its mutation to Glu is linked to formation of sporadic melanomas ${ }^{30}$.

\section{Conformational changes in p19 ${ }^{\text {INK4d }}$ and Cdk6}

Conformational changes in p19 ${ }^{\mathrm{INK} 4 \mathrm{~d}}$. The structure of $\mathrm{p} 19^{\mathrm{INK} 4 \mathrm{~d}}$ in solution and in the complex with Cdk6 can be superimposed with a root-mean-square (r.m.s.) deviation of $1.7 \AA$ (over the $\mathrm{C} \alpha$ carbons of residues 10-165). The difference is mainly due to a small longrange bending of the molecule and a small angular distortion in the packing of helices $\alpha 4$ and $\alpha 6$. The largest changes occur in the $\beta$ turns between ankyrins I/II, II/III and III/IV, which have few structural restraints in solution ${ }^{19}$, although they are not flexible (F.Y. Luh, S.J.A., P.J.D. and E.D.L., unpublished results).

Structure of Cdk6. In Fig. 3, the secondary structures, determined by crystallography, of Cdk2 (ref. 15) and Cdk6 in the p19 $9^{\text {INK4d }}$ complex are compared; they are very similar, but Cdk6 (and Cdk4) 
have two significant insertions (residues 70-72 and 86-90 in Cdk6). The $\mathrm{X}$-ray analysis shows that the first binds a calcium ion, which is coordinated octahedrally by the carboxylates of Glu 69 and Glu 72 and four water molecules. This insertion extends the helix by one turn, which may link it more firmly to loop L5, which anchors the two domains of Cdk6 together (see below). The second insertion in Cdk6 extends loop L6 and the $\beta$-sheet, involving Cdk6 strands $\beta 3$, $\beta 4$ and $\beta 5$. This insertion allows more extensive hydrogen bonding with loop L4, which ties the $\mathrm{N}$ terminus of the PLSTIRE helix more firmly to its tip than is possible in Cdk2 (Figs 2 and 5). The mitogenactivated protein kinase Erk2 also has a five-residue insertion between strands $\beta 4$ and $\beta 5$ (ref. 32). In Erk2, there is no interaction between the equivalent two loops, which indicates that this interaction in Cdk6 might be the result of $\mathrm{p} 19^{\mathrm{INK} 4 \mathrm{~d}}$ binding.

Conformational changes in Cdk6. Protein kinases have a 'closed' and an 'open' conformation. In the latter, the N-terminal $\beta$-sheet moves away from the active site ${ }^{33}$. Comparison with cAMP-dependent protein kinase $\mathrm{A}^{34}$ shows that in this structure, Cdk6, like those of Cdk2 (refs 15-17), has a 'closed' conformation.

The C-terminal domain of Cdk6 can be superimposed on the inactive Cdk2 (ref. 15), or Cdk2 in its active cyclin A complexes ${ }^{16,17}$, with an r.m.s. deviation of $\sim 0.5 \AA$ (over the $70 \alpha$-helical $\mathrm{C} \alpha$ atoms).
The N-terminal $\beta$-sheets can also be superimposed with an r.m.s. deviation of $\sim 0.4 \AA$ (over the $18 \beta$-sheet $\mathrm{C} \alpha$ atoms). Thus we expect that Cdk2 and Cdk6 by themselves will have very similar structures. A comparison of Cdk6/p19 ${ }^{\text {INK4d }}$ with Cdk2 (ref. 15) indicates that the $\mathrm{N}$-terminal domain of Cdk6 undergoes extensive movement on binding $\mathrm{p} 19^{\mathrm{INK} 4 \mathrm{~d}}$. Loop L5 connects the $\mathrm{C}$ terminus of the PLSTIRE helix $\alpha 1$ to Cdk6 strand $\beta 4$ (Fig. 4c). In all of the CDK structures, this loop, together with the linker (loop L7), anchors the N-terminal domain to the $\mathrm{C}$ terminus, thus providing a frame of reference for discussion (Fig. 5a).

Compared with isolated $\mathrm{Cdk} 2$, the $\mathrm{N}$-terminal domain in $\mathrm{p} 19^{\mathrm{INK} 4 \mathrm{~d}} / \mathrm{Cdk} 6$ is rotated approximately in the plane of the $\beta$ sheet about these fixed points, so that the different strands of the $\beta$-sheet now lie in positions similar to those seen in the $\mathrm{Cdk} 2 /$ cyclin A complex. In Cdk6, the whole $\beta$-sheet is also translated by about $5 \AA$ (Fig. 5b). In the absence of a structure of Cdk6 by itself, we cannot be sure that this movement of the N-terminal domain in Cdk6 is due to $19^{\text {INK4d }}$ binding; for example, p19 could stabilize an inactive conformation (see below) that is already present in the isolated Cdk6.

The $N$-terminal $\beta$-sheet moves as a whole, but this movement is not concerted with the movement of the $\mathrm{N}$ terminus of the PLSTIRE
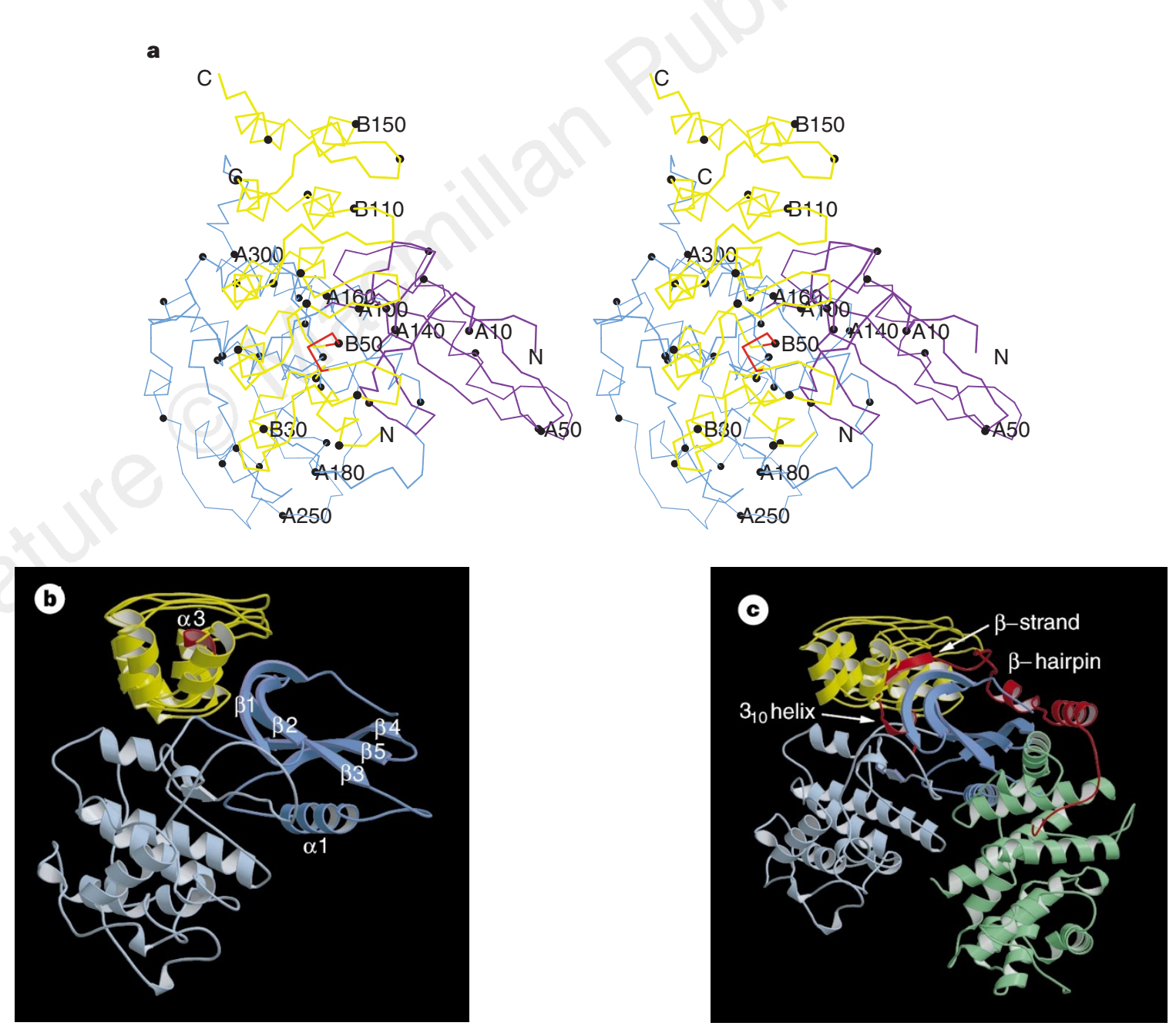

Figure 2 Three-dimensional structure of the p19 ${ }^{\mathrm{INK} 4 \mathrm{~d}} / \mathrm{Cdk} 6$ complex. a, Stereo view of the $\mathrm{C} \alpha$ trace of the $\mathrm{p} 19^{\mathrm{INK} 4 \mathrm{~d}} / \mathrm{Cdk} 6$ structure. Every tenth $\mathrm{C} \alpha$ atom is indicated by a solid ball. b. Schematic drawing of the same complex after rotation by $90^{\circ}$ about the $x$ axis. c, P19 INK4d and $p 27^{\text {Kip } 1}$ prevent each other binding to the CDK subunit in cyclin D/Cdk6. The structure in $\mathbf{c}$ is rotated $20^{\circ}$ about the $z$ axis compared to $\mathbf{b}$. In $\mathbf{a}$ and $\mathbf{b}$ p $19^{\mathrm{INK} 4 \mathrm{~d}}$ is coloured yellow, apart from helix $\alpha 3$ (residues 46-50), which is red. The C-terminal domain of Cdk6 is coloured light blue,

whereas the N-terminal domain, which undergoes extensive movement, is dark blue. In c, p19 ${ }^{\text {INK4d }}$ is coloured yellow, Cdk6 is light/dark blue, p27 $7^{\text {Kip1 }}$ is red and cyclin A is green. $\mathrm{p} 27^{\mathrm{Kip} 1}$ and cyclin A from the $\mathrm{p} 27^{\mathrm{Kip} 1} /$ cyclin A/Cdk2 structure ${ }^{40}$ were superimposed, as described in Fig. 5a, on p19 INK4d $/ \mathrm{Cdk6}$ (r.m.s. deviation was $0.46 \AA$ over 70 residues). Figures 2 and $5 a, b$ were produced using the programs MOLSCRIPT ${ }^{47}$ and RASTER3D ${ }^{48}$. 
helix $\alpha 1$, which is tethered by interactions between loops L4 and L6 (see above). Compared with the Cdk2 protein, the $\mathrm{N}$ terminus of the PLSTIRE helix $\alpha 1$ is pulled away by $\sim 2.0 \AA$ from the rest of the protein and it rotates about its axis by $\sim 30^{\circ}$ in a clockwise direction (viewed from the $\mathrm{N}$ terminus). This movement is in the opposite direction to that seen when cyclin A binds to Cdk2 (Fig. 5b), but the
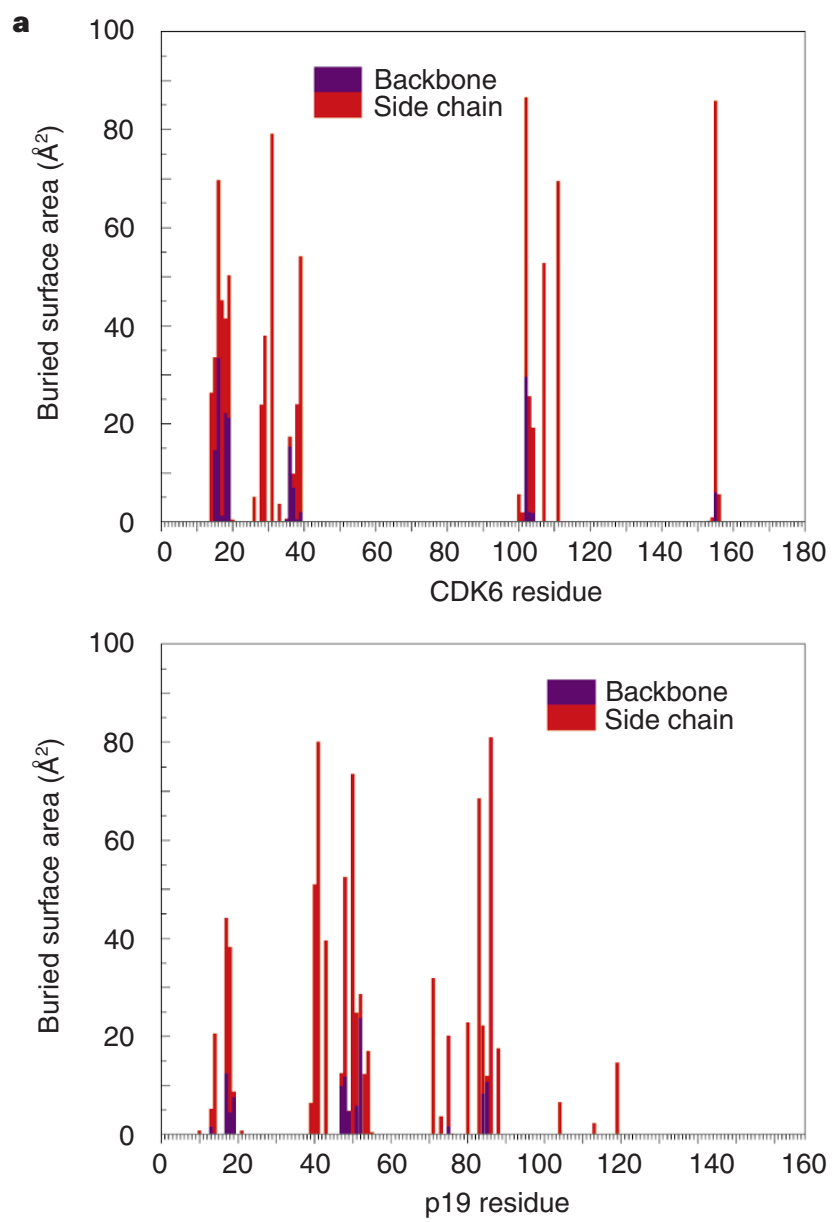

Figure 3 Sequence comparisons, secondary structure and residues buried in complex formation. a, Differences in solvent accessibility, calculated using the program NACCESS ${ }^{49}$, for the isolated $p 19^{1 N K 4 d}$ and Cdk6 subunits compared with the complex. Buried backbone and side chains are shown in blue and red, respectively. The interface contains around 17 charged and 14 large hydrophobic residues whose solvent accessibility is substantially reduced on complex formation. $\mathbf{b}$. Sequence of the mouse $\mathrm{p} 19^{\mathrm{INK} 4 \mathrm{~d}}$ protein showing the homology between the different ankyrin repeats and between the different members of the INK4 family. Positions in p16 $6^{\text {INK4a }}$ that are mutated in familial melanomas are indicated by an asterisk ${ }^{50}$; positions known to effect $16^{\text {INK4a }}$ binding or inhibition of Cdk 4 are indicated by a circumflex symbol ( ). .c, Sequences of Cdk6, Cdk4 and Cdk2. In addition to those discussed in the text, there is an insertion at residue 33 and deletions at residues 175, 194 and 251-252 compared to Cdk2. Positions 22 and 24 in Cdk4, where mutations inhibit binding of p16 ${ }^{\text {INK4a }}$ (ref. 28; M.S., unpublished results) and which are implicated in the formation of melanomas ${ }^{27,30,31}$ are indicated by an asterisk. In both $\mathbf{b}$ and $\mathbf{c}$, conserved residues involved in the interaction are coloured yellow (hydrophobic), orange (asparagine, glutamine, serine and threonine), green (glycine), red (acidic), magenta (histidine) and blue (basic); arrows (grey) and rectangles (white) indicate the positions of $\beta$-strands and $\alpha$-helices, respectively. rotation is in the same sense (this helix rotates $\sim 90^{\circ}$ in going from Cdk2 to Cdk2/cyclin $\mathrm{A}^{16}$ ).

\section{Implications for catalysis}

Cyclin-induced activation. Glu 61, in the PLSTIRE helix $\alpha 1$, is one of a triad of conserved catalytic residues (Lys 43, Glu 61 and Asp 163

b

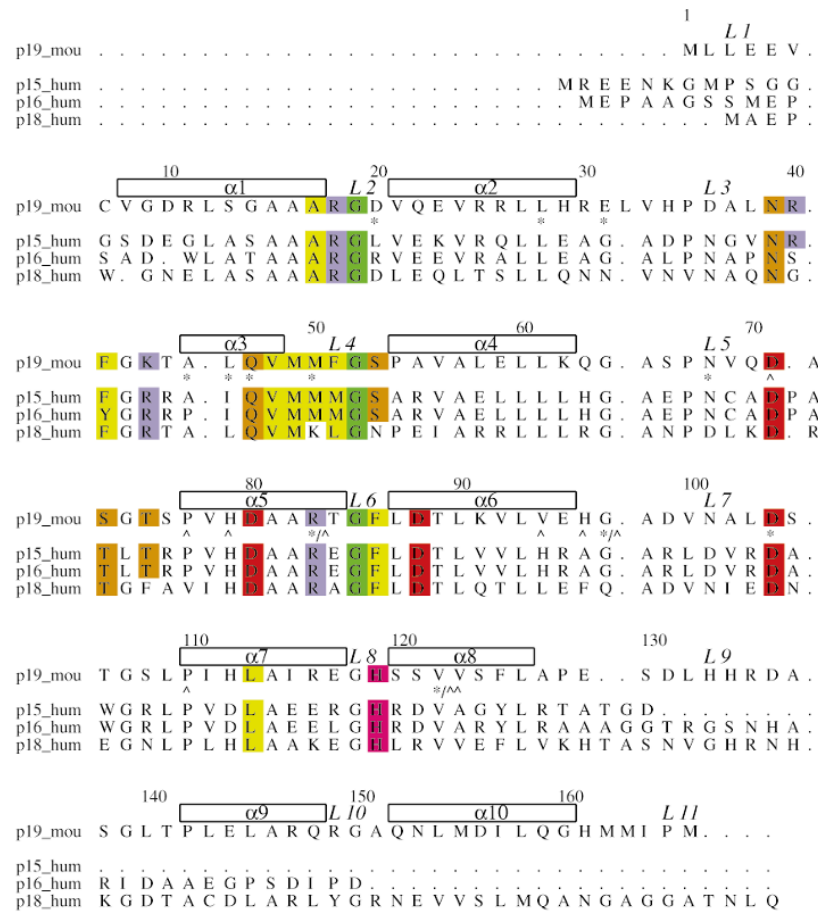

C
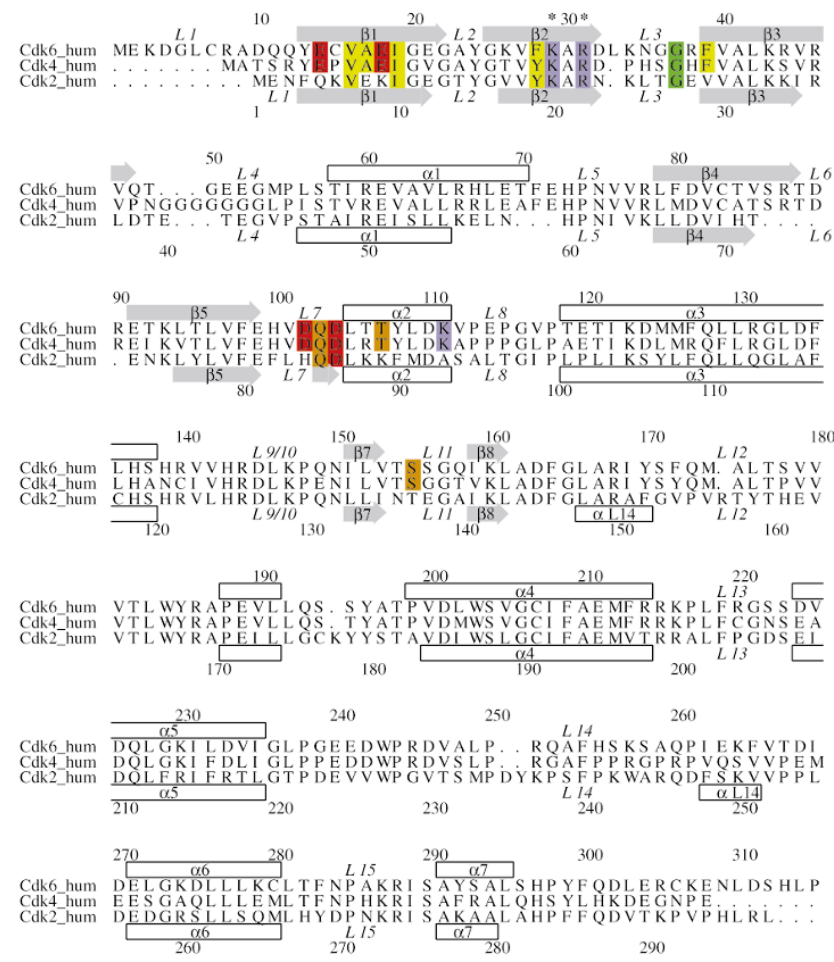

320

Cdk6_hum PS QNTSELNTA

Cdk4_hum
Cdk2_hum 


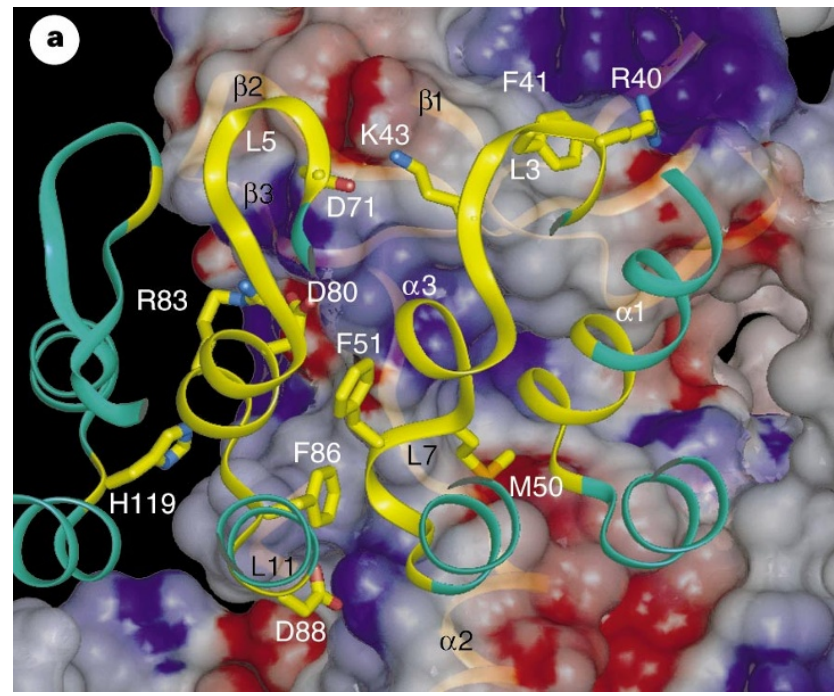

Figure 4 Surface representation of the $\mathrm{p} 19^{\mathrm{INK} 4 \mathrm{~d}} / \mathrm{Cdk} 6$ interface. The electrostatic potential at either the $\mathrm{p} 19^{\mathrm{INK} 4 \mathrm{~d}}$ or Cdk6 protein surface is contoured and colour coded at $-5.0 \mathrm{kT}$ (red) and $+5.0 \mathrm{kT}$ (blue). The interacting regions of both $\mathrm{p} 19^{\mathrm{INK} 4 \mathrm{~d}}$ and Cdk6 are yellow (otherwise green ( $\mathrm{p}^{19^{\mathrm{INK}} 4 \mathrm{~d}}$ ) and grey (Cdk6)); labels for the interacting protein are in white, whereas those for the contoured protein are in black. Side chains of residues involved in electrostatic interactions are red (negative) and blue (positive). Electrostatic interactions are formed between:

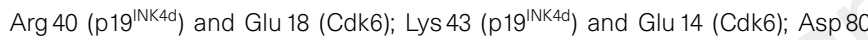

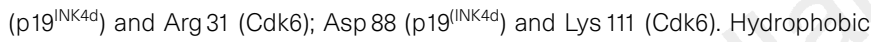
aromatic interactions are formed between Phe 41 (p19 ${ }^{\text {INK4d }}$ ) and Phe 28 (Cdk6),

in Cdk6) that are required for the correct orientation of ATP and coordination of magnesium in the active site of all eukaryotic kinases $^{33}$. In Cdk2, helix $\alpha 1$ and this glutamate move into the active site only on interaction with cyclin $\mathrm{A}^{16,17}$. If $\mathrm{p} 19^{\mathrm{INK} 4 \mathrm{~d}}$ binding prevented this movement it would inhibit the enzyme. In Cdk2 and $\mathrm{Cdk} 6 / \mathrm{p} 19^{\mathrm{INK} 4 \mathrm{~d}}$, the active-site Glu residues are in a similar position, whereas it is over $10 \AA$ away from the position seen in the active Cdk2/cyclin A structures, where it should interact with Lys 43 and coordinate the magnesium ion. Could cyclin binding move the PLSTIRE helix $\alpha 1$ and Glu 61 to their correct positions?

The similarity between the D-type cyclins and cyclin A suggests they will contact their respective CDKs in similar ways. For helix $\alpha 1$ to take up its active position, it must move in towards the Cterminal domain and loops L4 and L6 of Cdk6 must move out of the way of helices $\alpha 5$ and $\alpha 3$ in the cyclin ${ }^{16}$, respectively (Figs $2 \mathrm{c}$ and $5 \mathrm{~b}$ ). The interaction between loops L4 and L6 in p19 $9^{\mathrm{INK} 4 \mathrm{~d}} / \mathrm{Cdk} 6 \mathrm{might}$ therefore inhibit the necessary movement of helix $\alpha 1$. In Cdk4, however, several glycine residues are inserted in loop L4 that are not present in Cdk6 or Cdk2 (Fig. 3c). This sequence may therefore be unstructured in Cdk4, which would not favour a close interaction between loops L4 and L6. However, even if the interaction between L4 and L6 in Cdk6 did break down on cyclin binding, helix $\alpha 1$ might still be prevented from moving to its active position by a clash with the tip of loop L2 (Fig. 5b). In conclusion, the structure suggests that $\mathrm{p} 19^{\text {INK4d }}$ binding might prevent the cyclin-induced conformational change needed to activate the kinase. This conclusion is consistent with indications that $\mathrm{p} 16^{\mathrm{INK} 4 \mathrm{a}}$ binding might weaken the affinity of cyclin D for Cdk4 and Cdk6 in vivo ${ }^{35}$ and in vitro ${ }^{36}$.

Conformation of the T-loop. In Cdk2, the T-loop interacts with strand $\beta 1$ and obstructs the ATP-and substrate-binding sites, as well as the threonine side chain, which must be phosphorylated by $\mathrm{CAK}^{15}$. The conformation of the T-loop in Cdk6 (residues 164-183) is similar to that in Cdk2. As with Cdk2, however, there is no reason why the T-loop in Cdk6 could not move out of the way to the position seen in the Cdk2/cyclin A structures ${ }^{16,17}$ (Fig. 5). In fact, residues 173-179 have poor electron density, indicating conforma-

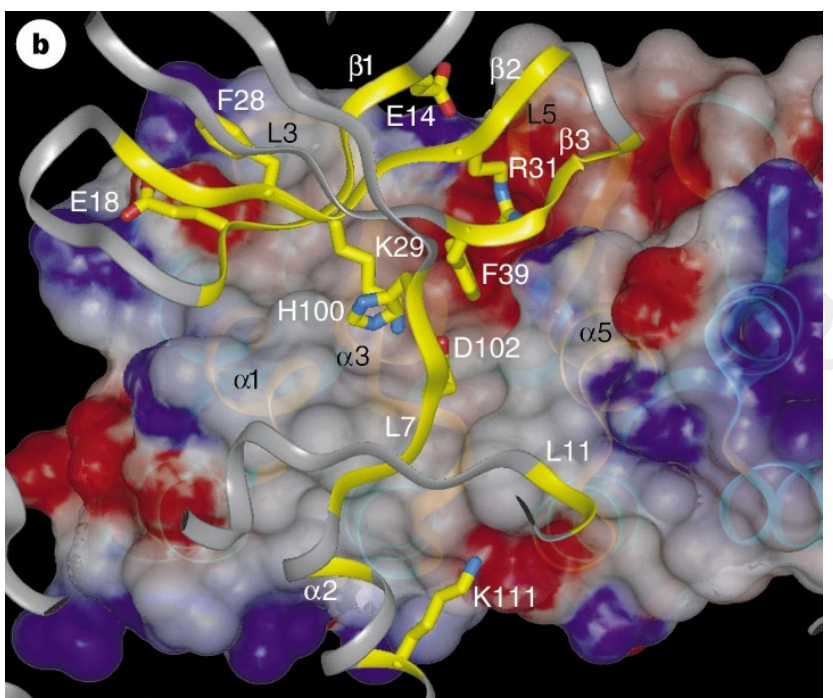

and between Phe 51 (p19 INK4d) and Phe 39 (Cdk6). Other p19 INK4d/Cdk6 interactions not mentioned in the text, or in Fig. 1, involve hydrogen bonds between the sidechains of Arg 31 (Cdk6) and Asp 71 (p19 ${ }^{\text {INK4d }}$ ) and between the side chain of Ser 155 (Cdk6) and the carbonyl groups of Thr 84 and Gly 85 (p19 INK4d). Two views of the structure are shown. a, Surface representation of Cdk6, in approximately the same orientation as in Fig. $2 a$, showing the interactions with $\mathrm{p} 19^{\text {INK4d }}$. b, Surface representation of $\mathrm{p} 19^{\mathrm{INK} 4 \mathrm{~d}}$, after rotating the structure by $180^{\circ}$, showing the interactions with Cdk6. This figure was produced using Insight II (MSI) and significant portions of the structure were clipped for clarity.

tional flexibility in this loop. The conformation of this loop is very different to that seen in a second structure of $\mathrm{p} 19^{\mathrm{INK} 4 \mathrm{~d}} / \mathrm{Cdk} 6$, which may be due to different crystallization conditions or different crystal packing $^{37}$. The two structures thus provide different views of the accessible conformations of this loop.

Implications for ATP binding. In Cdk2, ATP is bound by residues in the N-terminal domain (loop L2, strand $\beta 3$ including Lys 43, and Val 77 in strand $\beta 5$ ) by residues in the linker (loop L7), and by residues in the C-terminal domain (loop L10, strand $\beta 7$, and

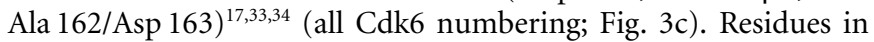
the linker L7 and in the C-terminal domain are in similar positions in $\mathrm{p} 19^{\mathrm{INK} 4 \mathrm{~d}} / \mathrm{Cdk} 6$ and in all of the Cdk2 structures, whereas residues in the N-terminal domain are in different positions (Fig. 5c).

P1 $19^{\mathrm{INK} 4 \mathrm{~d}}$ does not block ATP binding directly, although the side chain of Arg 18 has an alternative conformation where ATP must bind. When $\mathrm{p} 19^{\mathrm{INK} 4 \mathrm{~d}}$ interacts with Lys 29 and Asp 102 of Cdk6, the side chain of His 100 in Cdk6 moves into the adenine pocket of the ATP-binding site, and is held in this position by hydrogen bonding between the imidazole NE2 nitrogen and the carboxylate of Asp 102 (Figs 1 and 5c). This positioning of His 100 provides one possible mechanism by which ATP binding might be altered.

In the N-terminal domain, hydrogen bonding between the amides in the phosphate-binding loop L2 (residues Ala 23, Tyr 24 and Gly 25) and the $\beta$-phosphate of ATP is required to position the phosphates during catalysis. The side chain of Val 27 should also interact with the ribose and adenine rings ${ }^{17,34}$. Modelling of ATP into the $\mathrm{p} 19^{\mathrm{INK} 4 \mathrm{~d}} / \mathrm{Cdk} 6$ structure suggests that the movement of Cdk6 loop L2, relative to the other regions of the ATP-binding site, would prevent this hydrogen bonding and therefore prevent productive interaction with ATP (Fig. 5c).

\section{Competition between CDKIs}

The Cip/Kip and INK4 families of CDKIs compete for binding to Dtype cyclin/CDKs ${ }^{22,38,39}$. In the $\mathrm{p} 27^{\mathrm{Kip} 1} / \mathrm{Cdk} 2 /$ cyclin A complex, a $\beta$ hairpin in $\mathrm{p} 27^{\mathrm{Kip} 1}$ interacts with the $\mathrm{N}$-terminal $\beta$-sheet of Cdk 2 and a $\beta$-strand in $\mathrm{p} 27^{\mathrm{Kip} 1}$ displaces strand $\beta 1$ of $\mathrm{Cdk} 2$. In addition, a 


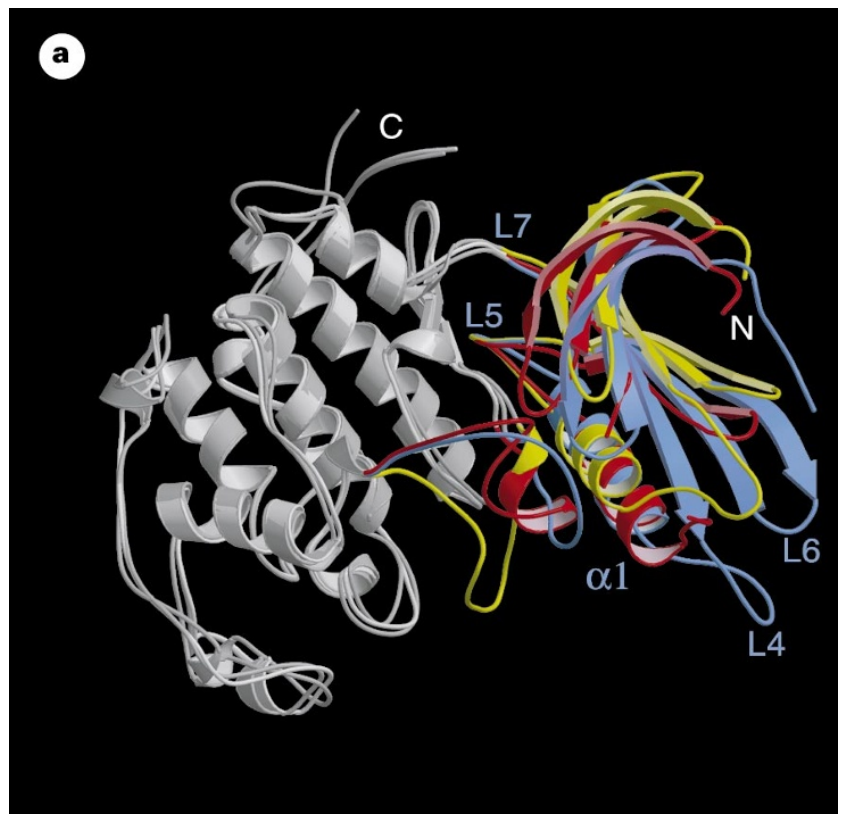

Figure 5 Comparison of ATP-binding sites in different kinases. a, Comparison of the structure of $p 19^{\mathrm{INK} 4 \mathrm{~d}} / \mathrm{Cdk} 6$ with those of Cdk2 (ref. 15) and Cdk2 from the cyclin A complex ${ }^{16,17}$. Cdk6 was superimposed on Cdk2 (r.m.s. deviation was $0.56 \AA$ over 70 residues) and Cdk2 from the cyclin $\mathrm{A}$ complex (r.m.s. deviation was $0.49 \AA$ over 70 residues) by aligning the $\mathrm{C} \alpha$ atoms in the $\alpha$-helices in the $\mathrm{C}$-terminal domain of both proteins. Loop L5 and the linker (loop L7) (Fig. 3c), which anchor the N- and C-terminal domains together, are labelled. $\mathbf{b}$. The same structures, showing only the $\mathrm{N}$-terminal domain, illustrating the changes in position of the $\mathrm{N}$-terminal $\beta$ sheet and helix $\alpha 1$. In both $\mathbf{a}$ and $\mathbf{b}$, the $\mathrm{N}$-terminal domains and T-loop are coloured red (Cdk2), yellow (Cdk2 from the cyclin A complex) and blue (Cdk6); other regions of all three proteins are coloured grey. In $\mathbf{b}$, helices $\alpha 3$ and $\alpha 5$ of cyclin A, which interact with PSTAIRE helix $\alpha 1$ in cyclin A/Cdk2 (refs 16, 17), are green. c, The ATP-binding site in Cdk6. Lys29, His 100 and Asp 102, which together might inhibit ATP binding, are labelled, as are key active-site residues and the phosphate-binding loop L2. ATP, from the active Cdk2/cyclin A complex ${ }^{17}$, is superimposed on the structure with the $\mathrm{N} 1$ and $\mathrm{N} 6$ adenine nitrogens making conserved hydrogen bonds with the carbonyl of Glu 99 and amide of Val 101, respectively ${ }^{17,34}$. The structures of Cdk6 and ATP are yellow and green, respectively. Carbon, nitrogen, oxygen and phosphorus atoms are yellow, blue, red and yellow, respectively. The structure of Cdk2 from the cyclin A/Cdk2 complex ${ }^{17}$ is blue.

p $27^{\text {Kip1 }} 3_{10}$ helix binds in the catalytic cleft ${ }^{40}$. As with Cdk2/cyclin $\mathrm{A}^{40}, \mathrm{p} 27^{\mathrm{Kip} 1}$ interacts with both the CDK and the cyclin components of Cdk4/cyclin D and Cdk6/cyclin $\mathrm{D}^{41}$. Comparison of the $\mathrm{p} 19^{\mathrm{INK} 4 \mathrm{~d}}$ / Cdk6 and $\mathrm{p} 27^{\mathrm{Kip} 1} / \mathrm{Cdk} 2 / \mathrm{cyclin}$ A structures shows that, although the interaction of the p27 $\beta$-hairpin might still be possible, the other p27 interactions would be inhibited by an INK4 protein. In other words, binding of one class of inhibitor should preclude the binding of the other (Fig. 2c). This is supported by experiments that show that either $\mathrm{p} 15^{\mathrm{INK} 4 \mathrm{~b}}$ (ref. 22), p16 ${ }^{\mathrm{INK} 4 \mathrm{a}}$ or p19 $9^{\mathrm{INK} 4 \mathrm{~d}}$ (D.B., S.W., X.X., L.B. and E.D.L., unpublished results) prevent binding of $\mathrm{p} 27^{\mathrm{Kip} 1}$ to the kinase subunit in cyclin D/CDKs and vice versa.

\section{Conclusions}

The structure of the $\mathrm{p} 19^{\mathrm{INK} 4 \mathrm{~d}} / \mathrm{Cdk} 6$ complex allows us to understand CDK regulation by the INK4 family of CDKIs. Close interactions between p $19^{\text {INK4d }}$ and loop L7 of Cdk6 are likely to be key determinants of specificity. The structure indicates that the interaction results in extensive movement of the $\mathrm{N}$-terminal domain of
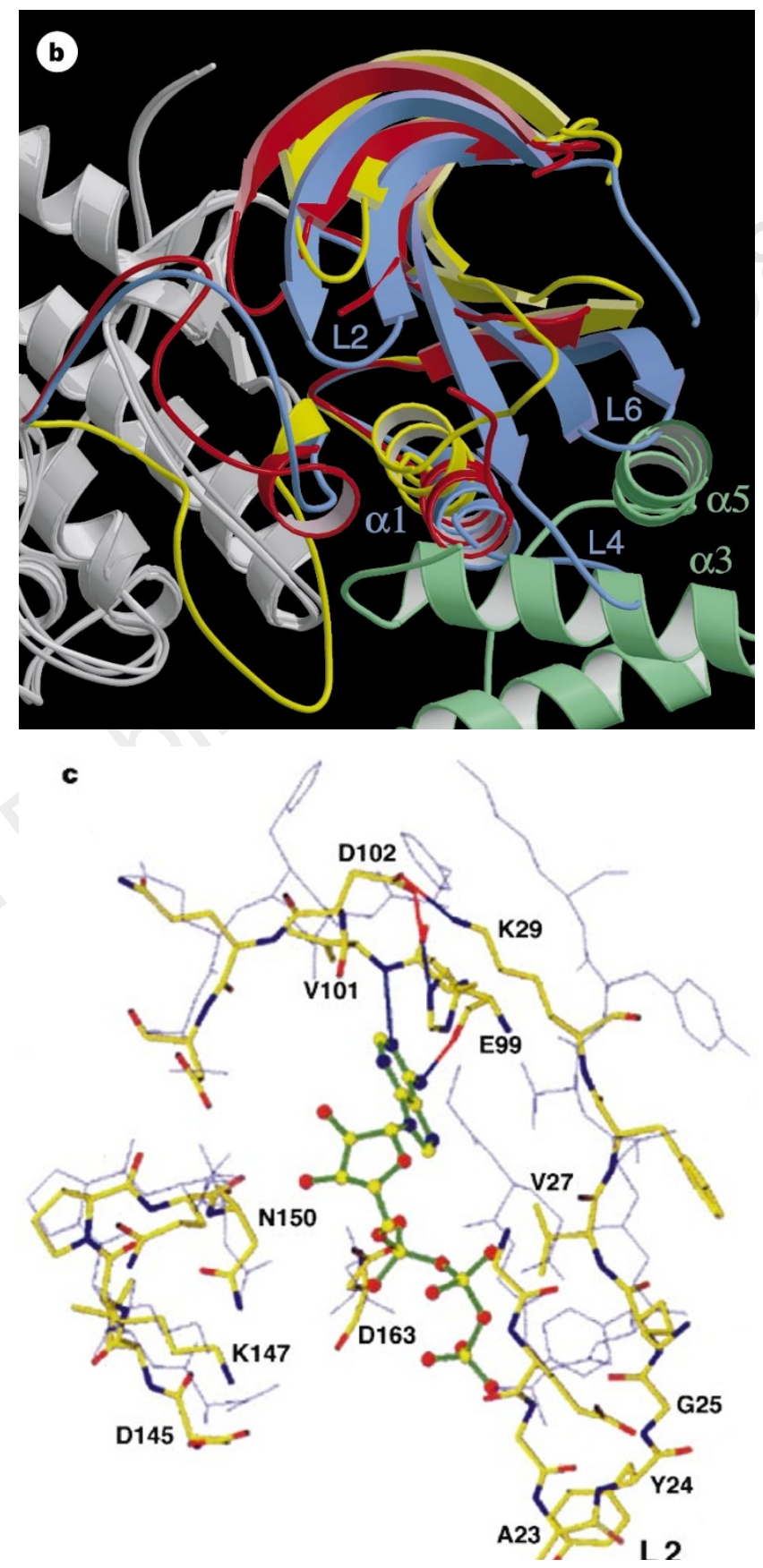

the kinase, relative to the $\mathrm{C}$ terminus, inhibiting productive binding with ATP and movement of the PLSTIRE helix to its active conformation. It is possible that conformational rearrangements could allow movement of this helix to its active conformation on cyclin binding, but productive ATP binding would be unlikely. The structure shows how the Cip/Kip and INK4 families of CDKI prevent each other from binding to the $\mathrm{CDK}$, allowing us to understand how they coordinate regulation of the cell cycle.

\section{Methods}

Protein expression and purification. Mouse p19 $9^{\mathrm{INK} 4 \mathrm{~d}}$ was expressed in Escherichia coli and purified as described ${ }^{19}$. Human Cdk6 was expressed in SF9 insect cells infected with a glutathione $S$-transferase (GST)-Cdk6 baculovirus. After infection, the cells were collected after $70 \mathrm{~h}$. Excess p $19^{\mathrm{INK} 4 \mathrm{~d}}$ protein was added before sonication and removal of cell debris by ultracentrifugation. The complex was purified on glutathione-sepharose resin (Pharmacia) and, after elution with $25 \mathrm{mM}$ glutathione, cleaved from GST by overnight digestion with thrombin. After treatment with antithrombin III resin, the GST was removed 
with glutathione-Sepharose resin and the complex was further purified on Mono-Q and Sephadex S-200 columns (Pharmacia). The protein ( $>95 \%$ pure) was concentrated to $\sim 25 \mathrm{mg} \mathrm{ml}^{-1}$ in $10 \mathrm{mM}$ Tris, $\mathrm{pH} 7.5,350 \mathrm{mM} \mathrm{NaCl}, 10 \mathrm{mM}$ DTT and 10\% glycerol. Electrospray mass spectrometry confirmed the identity and molecular mass of both proteins.

Crystallization and data collection. Crystals were grown at $4{ }^{\circ} \mathrm{C}$ by the hanging-drop vapour-diffusion method, after mixing the complex with an equal volume of buffer containing 6\% PEG 8000, 0.1 M MES, pH 6.5, and $0.1 \mathrm{M}$ calcium acetate. The crystals form in space group $P 2_{1} 2_{1} 2_{1}$ with $a=74.21$, $b=76.41$ and $c=93.80 \AA$ and contain one molecule of the complex in the asymmetric unit. Diffraction data were collected at synchrotron sources at room temperature using either a large MAR image-plate detector at beamline Px 9.5 (Daresbury Laboratory) or a CCD detector at beamline ID14 EH3 (ESRF Laboratory).

Molecular replacement. The structure was determined by molecular replacement (MR). The positions of the Cdk6 and $\mathrm{p} 19^{\mathrm{INK} 4 \mathrm{~d}}$ were determined by MR with the program AMORE ${ }^{42}$, using the structures of Cdk2 and p19 (PDB codes, 1 hck and lap7, respectively). The rotation and translation functions for Cdk6 were determined first and then fixed, before determining the translation function for $\mathrm{p} 19^{\mathrm{INK} 4 \mathrm{~d}}$. The correlation coefficient was 40.9 for $10-4 \AA$ data. The MR solution was consistent with results of site-directed mutagenesis of both p $19^{\text {INK4d }}$ and Cdk4, which showed that mutation of Phe 86 in p19 abolished binding to Cdk6 (data not shown) and that mutation to positions 22, 24 and 95-97 in Cdk4 abolished binding of p16 ${ }^{\mathrm{INK} 4 \mathrm{a}}$ (M.S., unpublished results). In addition, it was consistent with two-dimensional ${ }^{1} \mathrm{H}-{ }^{15} \mathrm{~N}$ HSQC NMR spectra that show that the amides of residues His 29, Arg 40, Gly 42, Thr 44, Ala 45, Ser 66 and Ser 76 in $19^{\text {INK4d }}$ have large changes in chemical shift, whereas those of Asp 10, Ser 13, Arg 18, Gly 19, Met 50, Phe 51, Gly 52 and Gly 85 have smaller shifts, on complex formation. The structure was refined using torsion-angle dynamics in X-PLOR ${ }^{43}$, followed by maximum-likelihood refinement using REFMAC $^{44}$. After successive rounds of rebuilding into SIGMAA-weighted maps ${ }^{45}$ using $\mathrm{O}$ (ref. 46), the final model consists of residues 5-309 of Cdk6, residues $6-165$ of $\mathrm{p} 19^{\mathrm{INK} 4 \mathrm{~d}}$, one calcium ion and 286 water molecules.

Received 15 May; accepted 20 July 1998

1. Sherr, C. J. Cancer cell cycles. Science 274, 1672-1677 (1996).

2. Morgan, D. O. Principles of CDK regulation. Nature 374, 131-134 (1995).

3. Parker, L. L., Sylvestre, P. J., Brynes, M. J., Liu, F. \& Piwnicaworms, H. Identification of a $95 \mathrm{Kda}$ WEE1-like tyrosine kinase in Hela-cells. Proc. Natl Acad. Sci.USA 92, 9638-9642 (1995).

4. Kumagai, A. \& Dunphy, W. G. The Cdc25 protein controls tyrosine dephosphorylation of the Cdc2 protein in a cell-free system. Cell 64, 903-914 (1991).

5. Sherr, C. \& Roberts, J. Inhibitors of mammalian G1 cyclin-dependent kinases. Genes Dev. 9, 1149 1153 (1995).

6. Harper, J. W. in Checkpoint Control and Cancer (ed Kastan, M. B.) Vol. 29, 91-107 (CSHL Press, New York, 1997).

7. Soos, T. J. et al. Formation of p27-CDK complexes during the human mitotic cell cycle. Cell Growth Differ. 7, 135-146 (1996).

8. Poon, R. Y. C., Toyoshima, H. \& Hunter, T. Redistribution of the CDK inhibitor p27 between different cyclin-CDK complexes in the mouse fibroblast cell cycle and in cells arrested with lovastatin or ultraviolet irradiation. Mol. Biol. Cell 6, 1197-1213 (1995).

9. Serrano, M., Hannon, G. J. \& Beach, D. A new regulatory motif in cell-cycle control causing specific inhibition of cyclin D/CDK4. Nature 366, 704-707 (1993).

10. Hannon, G. J. \& Beach, D. $\mathrm{p} 15^{\mathrm{INK} 4 \mathrm{~B}}$ is a potential effector of TGF- $\beta$-induced cell cycle arrest. Nature 371, 257-261 (1994).

11. Hirai, H., Roussel, M. F., Kato, J-Y., Ashmun, R. A. \& Sherr, C. J. Novel INK4 proteins, p19 and p18, are specific inhibitors of the cyclin D-dependent kinases CDK4 and CDK6. Mol. Cell. Biol. 15, 2672-2681 (1995).

12. Chan, F. K. M., Zhang, J., Cheng, L., Shaprio, D. N. \& Winoto, D. A. Identification of human and mouse p19, a novel CDK4 and CDK6 inhibitor with homology to p16 ${ }^{\mathrm{INK} 4}$. Mol. Cell. Biol. 15, 2682 2688 (1995).

13. Guan, K. et al. Isolation and characterization of $\mathrm{p} 19^{\mathrm{INK} 4 \mathrm{~d}}$, a p16 related inhibitor specific to CDK6 and CDK4. Mol. Biol. Cell 7, 57-70 (1996).

14. Weinberg, R. A. The retinoblastoma protein and cell cycle control. Cell 81, 323-330 (1995).

15. De Bondt, H. L. et al. Crystal structure of cyclin-dependent kinase 2. Nature 363, 595-602 (1993).

16. Jeffrey, P. D. et al. Mechanism of CDK activation revealed by the structure of a cyclin-CDK2 complex. Nature 376, 313-320 (1995).

17. Russo, A. A., Jeffrey, P. D. \& Pavletich, N. P. Structural basis of cyclin-dependent kinase activation by phosphorylation. Nature Struct. Biol. 3, 696-700 (1996).
18. Bork, P. Hundreds of ankyrin-like repeats in functionally diverse proteins: mobile modules that cross phyla horizontally. Proteins Struct. Funct. and Genet. 17, 363-374 (1993).

19. Luh, F. Y. et al. Structure of the cyclin-dependent kinase inhibitor p19 ${ }^{\text {INK4d }}$. Nature 389, 999-1003 (1997).

20. Venkataramani, R., Swaminathan, K. \& Marmorstein, R. Crystal structure of the CDK4/6 inhibitory protein $\mathrm{p}^{18^{\mathrm{INK} 4 \mathrm{C}}}$ provides insights into ankyrin-like repeat structure/function and tumor-derived p16 ${ }^{\mathrm{INK} 4}$ mutations. Nature Struct. Biol. 5, 74-81 (1998).

21. Byeon, I.-J. L. et al. Tumor suppressor $\mathrm{pl}^{1 \mathrm{NK} 4 \mathrm{a}}$ : Determination of solution structure and analyses of its interaction with cyclin-dependent kinase 4. Mol. Cell 1, 421-431 (1998).

22. Reynisdottir, I. \& Massagué, J. The subcellular locations of $\mathrm{p} 15^{\mathrm{INK} 4 \mathrm{~b}}$ and $\mathrm{p} 27^{\mathrm{Kip} 1}$ coordinate their inhibitory interactions with Cdk4 and Cdk2. Genes Dev. 11, 492-503 (1997).

23. Yang, R., Gombart, A. F., Serrano, M. \& Koeffler, H. P. Mutational effects on the $\mathrm{p} 16^{\mathrm{INK} 4 \mathrm{a}}$ tumoursuppressor protein. Cancer Res. 55, 2503-2506 (1995).

24. Gorina, S. \& Pavletich, N. P. Structure of the p53 tumor suppressor bound to the ankyrin and $\mathrm{SH} 3$ domains of 53BP2. Science 274, 1001-1005 (1996).

25. Batchelor, A. H., Piper, D. E., de la Brousse, F. C., McKnight, S. L. \& Wolberger, C. The structure of $\mathrm{GABP} \alpha / \beta$ : an ETS domain-ankyrin repeat heterodimer bound to DNA. Science 279, 1037-1041 (1998)

26. Zhang, B. \& Peng, Z.-Y. Defective folding of mutant $\mathrm{p} 16^{\mathrm{INK} 4 \mathrm{a}}$ proteins encoded by tumor-derived alleles. J. Biol. Chem. 271, 28734-28737 (1996).

27. Wölfel, T. et al. A p16 $6^{\mathrm{INK} 4 \mathrm{~A}}$-insensitive CDK4 mutant targeted by cytolytic T-lymphocytes in a humanmelanoma. Science 269, 1281-1284 (1995).

28. Coleman, K. G. et al. Identification of Cdk4 sequences involved in Cyclin D1 and p16 binding. J. Biol. Chem. 272, 18869-18874 (1997).

29. Zuo, L. et al. Germline mutations in the $16^{\mathrm{INK} 4 \mathrm{a}}$ binding domain of CDK4 in familial melanoma. Nature Genet. 12, 97-99 (1996).

30. Tsao, H., Benoit, E., Sober, A. J., Thiele, C. \& Haluska, F. G. Novel mutation in the $p 16 / C D K N 2 A$ binding region of cyclin-dependent kinase-4 gene. Cancer Res. 58, 109-113 (1998).

31. Soufir, N. et al. Prevalence of p16 and CDK4 germline mutations in 48 melanoma-prone families in France. Hum. Mol. Genet. 7, 209-216 (1998).

32. Zhang, F., Strand, A., Robbins, D., Cobb, M. H. \& Goldsmith, E. J. Atomic structure of the MAP kinase ERK2 at $2.3 \AA$ resolution. Nature $367,704-710$ (1994).

33. Taylor, S. S. \& Radzio-Andzelm, E. Three protein kinase structures define a common motif. Structure 2, 345-355 (1994)

34. Zheng, J. H. et al. Crystal structure of the catalytic subunit of cAMP-dependent protein kinase complexed with MgATP and peptide inhibitor. Biochemistry 32, 2154-2161 (1993).

35. Parry, D., Bates, S., Mann, D. J. \& Peters, G. Lack of cyclin D-Cdk complexes in Rb-negative cells correlates with high levels of $\mathrm{p}^{16^{\mathrm{INK} 4 / 4 \mathrm{MTS} 1}}$ tumour suppressor gene product. EMBO J. 14, 503-511 (1995).

36. DellaRagione, F. et al. Biochemical characterisation of $\mathrm{p} 16^{\mathrm{INK} 4}$ - and $\mathrm{p} 18$-containing complexes in human cell lines. J. Biol. Chem. 271, 15942-15949 (1996).

37. Russo, A. A., Tong, L., Lee, J.-O., Jeffrey, P. D. \& Pavletich, N. P. Structural basis for inhibition of the cyclin-dependent kinase Cdk6 by the tumour suppressor p16 $6^{\text {INK4a }}$. Nature 395, 237-244 (1998).

38. Reynisdottir, I., Polyak, A., Iavarone, A. \& Massagué, J. Kip/Cip and INK4D CDK inhibitor cooperate to induce cell cycle arrest in response to TGF- $\beta$. Genes Dev. 9, 1831-1845 (1995).

39. Sandhu, C. et al. TGF 3 stabilizes $\mathrm{p} 15^{\mathrm{INK} 46}$ protein, increases $\mathrm{p} 15^{\mathrm{INK} 46} / \mathrm{CDK} 4$ complexes, and inhibits cycD1/CDK4 association in human mammary epithelial cells. Mol. Cell. Biol. 17, 2458-2467 (1997)

40. Russo, A. A., Jeffrey, P. D., Patten, A. K., Massagué, J. \& Pavletich, N. P. Crystal structure of the p27 ${ }^{\text {Kip1 }}$ cyclin-dependent kinase inhibitor bound to the cyclin A-Cdk2 complex. Nature 382, 325-331 (1996).

41. Vlach, J., Hennecke, S. \& Amati, B. Phosphorylation-dependent degradation of the cyclin-dependent kinase inhibitor p27 $7^{\text {Kip1 }}$. EMBO J. 16, 5334-5344 (1997).

42. Collaborative computing project, Number 4 . The CCP4 suite: programs for protein crystallography. Acta Crystallogr. D 50, 760-763 (1994).

43. Brünger, A. T. X-PLOR, Version 3.1, A System for X-Ray Crystallography and NMR (Yale Univ. Press, New Haven and London, 1992).

44. Murshudov, G. N., Vagin, A. A. \& Dodson, E. J. Refinement of macromolecular structures by the maximum-likelihood method. Acta Crystallogr. D 53, 240-255 (1997).

45. Read, R. J. Improved Fourier coefficients for maps using phases from partial structures with errors. Acta Crystallogr. A 42, 140-149 (1986).

46. Jones, T. A., Zou, J. Y., Cowan, S. W. \& Kjeldgaard, M. Improved methods for building protein models in electron-density maps and the location of errors in these models. Acta Crystallogr. A 47, 110-119 (1991).

47. Kraulis, P. J. MOLSCRIPT: a program to produce both detailed and schematic plots of protein structures. J. Appl. Crystallogr. 24, 946-950 (1991).

48. Merrit, E. A. \& Murphy, M. E. Raster3D. A program for photorealistic molecular graphics. Acta Crystallogr. D 50, 869-873 (1994)

49. Hubbard, S. J. \& Thornton, J. M. 'NACCESS' computer program (Department of Biochemistry and Molecular Biology, Univ. College London, 1993).

50. Foulkes, W. D., Flanders, T. Y., Pollock, P. M. \& Hayward, N. K. The CDKN2A (p16) gene and human cancer. Mol. Med. 3, 5-20 (1997).

Acknowledgements. We thank C. J. Sherr (Howard Hughes Medical Institute) for the plasmid expressing GST-p19 $9^{\text {INK4d }}$; A. Raine for computer programming: M. Nilges for X-PLOR scripts; I. Tickle for advice; F Luh for the selectively protonated $19^{\mathrm{INK} 4 \mathrm{~d}} ; \mathrm{J}$. Eckstein for help with molecular graphics; and E. Duke, W. Luh for the selectively protonated $\mathrm{p} 19^{\mathrm{INK} 4 \mathrm{~d}}$; J. Eckstein for help with molecular graphics; and E. Duke, W.
Burmeister and R. C. Kehoe for help with data collection. This work was supported by grants from the Burmeister and R. C. Kehoe for help with data collection. This work was supported by grants from the
BBSRC and the Wellcome Trust. D.H.B. is supported by a studentship from the MRC. M.S. is supported by a grant from DGICYT, Spain, and by a core grant to the Department of Immunology and Oncology from Pharmacia-Upjohn and the Spanish Research Council. The Cambridge Centre for Molecular Recognition is supported by the BBSRC and the Wellcome Trust.

Correspondence and requests for materials should be addressed to E.D.L. (e-mail: e.d.laue@bioc.cam. ac.uk). The coordinates have been deposited in the Brookhaven Protein Data Bank (accession number lblx). 
eyecup allowed to dark-adapt for at least $1 \mathrm{~h}$. Glass microelectrodes filled with $3 \mathrm{M} \mathrm{K}$-acetate and $200 \mathrm{mM} \mathrm{KCl}(150-200 \mathrm{M} \Omega)$ were used for intracellular recording from horizontal cells. Voltage responses to light flashes were amplified with a WPI M707 Microprobe system and analysed using BasicFastlab software. Solutions at $21-23^{\circ} \mathrm{C}$ were continuously superperfused at $1 \mathrm{ml} \mathrm{min}^{-1}$. Control saline contained (in $\mathrm{mM}$ ): $95 \mathrm{NaCl}, 2.5 \mathrm{KCl}, 3 \mathrm{CaCl}_{2}, 1.5$ $\mathrm{MgCl}_{2}, 30 \mathrm{NaHCO}_{3}$ and $1 \mathrm{mg} \mathrm{ml}^{-1}$ glucose, and was bubbled continuously with $95 \% \mathrm{O}_{2} / 5 \% \mathrm{CO}_{2}$ to maintain a $\mathrm{pH}$ of 7.6 . Each recording was obtained from individual horizontal retinal cells exposed for $1 \mathrm{~h}$ to control saline, saline containing $\mathrm{N}^{\mathrm{G}}$-nitro-L-arginine (L-NNA; Calbiochem). L-arginine (Sigma) or $1 H$-[1,2,4] oxadiazolo[4,3-a]quinoxalin-1-one (ODQ; Tocris).

Received 23 June; accepted 5 September 1997.

1. Yau, K.-W. \& Baylor, D. A. Cyclic GMP-activated conductance of retinal photoreceptor cells. Annu Rev. Neurosci. 12, 289-327 (1989).

2. Koutalos, Y. \& Yau, K.-W. Regulation of sensitivity in vertebrate rod photoreceptors by calcium. Trends Neurosci. 19, 73-81 (1996).

3. Rieke, F. \& Schwartz, E. A. A cGMP-gated current can control exocytosis at cone synapses. Neuron 13, 863-873 (1994)

4. Garthwaite, J., Charles, S. J. \& Chess-Williams, R. Endothelium-derived relaxing factor release on activation of NMDA receptors suggests role as intercellular messenger in the brain. Nature 336, 385388 (1988).

O'Dell, T. J., Hawkins, R. D., Kandel, E. R. \& Arancio, O. Tests of the roles of two diffusible substances in long-term potentiation: evidence for nitric oxide as a possible early retrograde messenger. Proc. Nat Acad. Sci. USA 88, 11285-11289 (1991).

6. Schuman, E. M. \& Madison, D. V. Nitric oxide and synaptic function. Annu. Rev. Neurosci. 17, 153 183 (1994).

7. Maricq, A. V. \& Korenbrot, J. I. Calcium and calcium-dependent chloride currents generate action potentials in solitary cone photoreceptors. Neuron 1, 503-515 (1988).

8. Wilkinson, M. F. \& Barnes, S. The dihydropyridine-sensitive calcium channel subtypes in cone photoreceptors. J. Gen. Physiol. 107, 621-630 (1996).

9. Zimmerman, A. L., Yamanaka, G., Eckstein, F., Baylor, D. A. \& Stryer, L. Interaction of hydrolysisresistant analogs of cyclic GMP with the phosphodiesterase and light-sensitive channel of retinal rod outer segments. Proc. Natl Acad. Sci. USA 82, 8813-8817 (1985).

10. Watanabe, S.-I. \& Matthews, G. Regional distribution of cGMP-activated ion channels in the plasma membrane of the rod photoreceptor. J. Neurosci. 8, 2334-2337 (1988).

11. Liepe, B. A., Stone, C., Koistinaho, J. \& Copenhagen, D. R. Nitric oxide synthase in Muller cells and neurons of salamander and fish retina. J. Neurosci. 14, 7641-7654 (1994).

12. Kurenny, D. R. et al. Modulation of ion channels in rod photoreceptors by nitric oxide. Neuron 13 315-324 (1995).

13. Koch, K. W., Lambrecht, H. G., Haberecht, M., Redburn, D. \& Schmidt, H. H. Functional coupling of $\mathrm{a} \mathrm{Ca}^{2+} /$ calmodulin-dependent nitric oxide synthase and a soluble guanylyl cyclase in vertebrate photoreceptor cells. EMBO J. 13, 3312-3320 (1994).

14. Baylor, D. A., Fuortes, M. G. F. \& O'Bryan, P. M. Receptive fields of single cones in the retina of the turtle. J. Physiol. (Lond.) 214, 265-294 (1971).

15. Piccolino, M., Neyton, J. \& Gerschenfeld, H. M. Centre-surround antagonism in small-field luminosity horizontal cells of turtle retina. J. Neurophysiol. 45, 363-375 (1981).

16. Wu, S. M. Synaptic transmission in the outer retina. Annu. Rev. Physiol. 56, 141-168 (1994).

17. Garthwaite, J. et al. Potent and selective inhibition of nitric oxide-sensitive guanylyl cyclase by $1 \mathrm{H}$ [1,2,4] oxadiazolo[4,3-a] quinoxalin-1-one. Mol. Pharmacol. 48, 184-188 (1995).

18. Broillet, M.-C. \& Firestein, S. Direct activation of the olfactory cyclic nucleotide-gated channel through modification of sulfhydryl groups by NO compounds. Neuron 16, 377-385 (1996).

19. Copenhagen, D. R. \& Jahr, C. E. Release of endogenous excitatory amino acids from turtle photoreceptors. Nature 341, 536-539 (1989)

20. Tachibana, M. \& Okada, T. Release of endogenous excitatory amino acids from ON-type bipolar cells isolated from the goldfish retina. J. Neurosci. 11, 2199-2208 (1991).

21. Mulsch, A., Busse, R., Liebau, S. \& Forstermann, U. LY83583 interferes with the release of endothelium-derived relaxing factor and inhibits soluble guanylate cyclase. J. Pharmacol. Exp. Ther 247, 282-288 (1988)

22. Barnes, S. \& Hille, B. Ionic channels of the inner segment of tiger salamander cone photoreceptors. $J$ Gen. Physiol. 94, 719-743 (1989).

23. Normann, R. A. \& Perlman, I. Signal transmission from red cones to horizontal cells in the turtle retina. J. Physiol. (Lond.) 286, 509-524 (1979).

24. Meffert, M. K., Premack, B. A. \& Schulman, H. Nitric oxide stimulates $\mathrm{Ca}^{2+}$-independent synaptic vesicle release. Neuron 12, 1235-1244 (1994).

25. Arancio, O., Kandel, E. R. \& Hawkins, R. D. Activity-dependent long-term enhancement of transmitter release by presynaptic $3^{\prime}, 5^{\prime}$-cyclic GMP in cultured hippocampal neurons. Nature 376, 74-80 (1995).

26. Kingston, P. A., Zufall, F. \& Barnstable, C. J. Rat hippocampal neurons express genes for both rod retinal and olfactory cyclic nucleotide-gated channels: novel targets for cAMP/cGMP function. Proc. Natl Acad. Sci. USA 93, 10440-10445 (1996).

27. Bradley, J. et al. Functional expression of the heteromeric "olfactory" cyclic nucleotide-gated channel in the hippocampus: a potential effector of synaptic plasticity in brain neurons. J. Neurosci. 17, 1993 2005 (1997).

28. Finn, J. T., Grunwald, M. E. \& Yau, K.-W. Cyclic nucleotide-gated ion channels: an extended family with diverse functions. Annu. Rev. Physiol. 58, 395-426 (1996).

29. Horn, R. Estimating the number of channels in patch recordings. Biophys. J. 60, 433-439 (1991).

30. Dixon, D. B. \& Copenhagen, D. R. Metabotropic glutamate receptor-mediated suppression of an inward rectifier current is linked via a cGMP cascade. J. Neurosci. 1997 (in the press).

30. Barnes, S. \& Deschenes, M. C. Contribution of $\mathrm{Ca}$ and $\mathrm{Ca}$-activated $\mathrm{Cl}$ channels to regenerative depolarization and membrane bistability of cone photoreceptors. J. Neurophysiol. 68, 745-755 (1992).

Acknowledgements. We thank D. Eng for help with preliminary experiments; S. Nawy and R. Bookman for comments; and D. Dixon for advice on horizontal cell culture. This work was supported by grants from the NIH and the American Heart Association (R.H.K.), and the MRC Canada and the AHFMR (S.B.).

Correspondence and requests for materials should be addressed to R.H.K. (e-mail: rkramer@mednet. med.miami.edu)

\section{Identification and role of adenylyl cyclase in auxin signalling in higher plants}

\author{
Takanari Ichikawa, Yoshihito Suzuki, Inge Czaja, \\ Carla Schommer, Angela Leßnick, Jeff Schell \\ \& Richard Walden
}

Max Planck Institut für Züchtungsforschung, Carl von Linné Weg 10, D-50829 Köln, Germany

Cyclic AMP is an important signalling molecule in prokaryotes and eukaryotes ${ }^{1}$, but its significance in higher plants has been generally doubted ${ }^{2}$ because they have low adenylyl cyclase activity and barely detectable amounts of cAMP $^{3}$. Here we used activation T-DNA tagging to create tobacco cell lines that can proliferate in the absence of the phytohormone auxin in the culture media ${ }^{4,5}$. The sequence tagged in one line, axi 141, was used to isolate a complementary DNA encoding adenylyl cyclase, the first from a higher plant. Sequence analysis reveals that the tobacco adenylyl cyclase is probably soluble, contains characteristic leucine-rich repeats, and bears similarity with adenylyl cyclase from the yeast Schizosaccharomyces pombe. Expression of the cDNA in Escherichia coli results in an increase in endogenous cAMP levels, and in yeast its expression functionally complements the cry1 mutation. Tobacco protoplasts treated with cAMP, or the adenylyl cyclase activator forskolin, no longer require auxin to divide. This finding, together with the observation that the adenylyl cyclase inhibitor dideoxyadenosine inhibits cell proliferation in the presence of auxin, suggests that cAMP is involved in auxin-triggered cell division in higher plants.

The molecular basis of auxin action in plants is little understood, and to address this we have developed the technique of activation TDNA tagging ${ }^{4,5}$. This involves transforming tobacco cells with a gene tag containing multiple transcriptional enhancers so that, once the tag has been inserted into the genome, expression of flanking plant DNA becomes deregulated, producing a dominant mutation. This allows direct selection for a defined phenotype, and we have selected for cells that proliferate in culture in the absence of exogenously applied auxin, with the idea that tagged genes are likely to play a role in auxin signal transduction. Genetic segregation (data not shown) and Southern analysis revealed that the auxin-independent tobacco cell line axi 141 contains a single non-rearranged T-DNA insert (Fig. 1a, b). Plasmid rescue using EcoRI-digested axi 141 genomic DNA resulted in the recovery of pAI411 containing the T-DNA flanked by approximately 3.0 kilobases $(\mathrm{kb})$ and $7.5 \mathrm{~kb}$ of plant DNA at the right and left T-DNA borders, respectively (Fig. 1a). Transfecting tobacco protoplasts with deletion derivatives of pAI411 followed by screening for auxin-independent growth indicated that the responsible sequence was located near the left T-DNA border (Fig. 1a). The ApaI-ClaI fragment of pAI411 was used to screen a cDNA library from dividing tobacco protoplasts, and resulted in pB149 containing an insert of 1,600 base pairs (bp) (GenBank accession number: AF026389). Southern analysis using pB149 indicates that the sequence is present in low copy number in the tobacco genome, and revealed a restriction fragment length polymorphism between untransformed tobacco and axi 141, indicating that the T-DNA had inserted into an 11-kb EcoRI fragment of tobacco genomic DNA (Fig. 1b). Northern analysis using RNA isolated from protoplasts from untransformed and axi 141 plants cultured in the presence or absence of auxin revealed a band of approximately $1.5 \mathrm{~kb}$ (Fig. 1c).

* Present address: Department of Applied Biology and Chemistry, University of Tokyo, 1-1-1 Yayoi, Bunkyo-ku, Tokyo 113, Japan. 
Quantification of hybridization intensities by comparison with an actin probe revealed that axi $141 \mathrm{mRNA}$ accumulates in protoplasts from untransformed plants cultivated both in the presence and the absence of auxin. The axi 141 protoplasts accumulate highest levels of transcript in the absence of auxin, suggesting that in the mutant line there is a feedback transcriptional regulation in the presence of auxin, as seen previously in another auxin-independent mutant axi 1 (ref. 6).

Plants regenerated from axi 141 cells display no obvious morphological differences compared with untransformed tobacco. However, axi 141 protoplasts proliferate in culture not only in the absence of exogenously applied auxin but also at levels of auxin that normally inhibit division (Fig. 2a). When the cDNA insert of pB149 is cloned between the promoter and polyadenylation signals of the CaMV 35S RNA to produce pRAI14-9 and used in protoplast transformation, transfected protoplasts were able to grow in the absence of exogenously applied auxin (Fig. 2b). Sequencing pB149 revealed a long open reading frame (ORF) potentially encoding a 406-amino-acid peptide, a 105-bp 5' leader sequence containing seven translational stop sites, a 160-bp 3' untranslated region, and a poly(A) tail. We have called the gene encoded by pB149 axi 141 (for auxin independent). Analysis of the predicted protein encoded by axi 141 shows that it contains blocks of leucine-rich repeats, and sequence comparison reveals that the carboxy terminus of the gene contains low-level similarity to the $\mathrm{C}$ terminus of adenylyl cyclase of S. pombe ${ }^{7}$, arrayed in regions of sequence identity ranging from $23 \%$ to $71 \%$ (Fig. $2 \mathrm{c}$ ).

To confirm the identity of axi 141, the coding region of pB149 was cloned into an E. coli expression vector, $\mathrm{pRSET}^{8}$, transformed into E. coli, and the resulting cAMP levels in cell extracts were measured. Bacteria containing the plasmid expressing axi 141, checked by western analysis (data not shown), consistently accumulated 50\% more cAMP than bacteria transformed with the expression vector lacking an insert (Fig. 3a). In yeast, the CYR1 locus encodes the structural gene for adenylyl cyclase ${ }^{9}$. In the absence of cAMP, growth of cyr 1 mutants is arrested at the G1 phase of the cell cycle 9 . Thus, axi 141 was cloned into a yeast expression vector and transformed

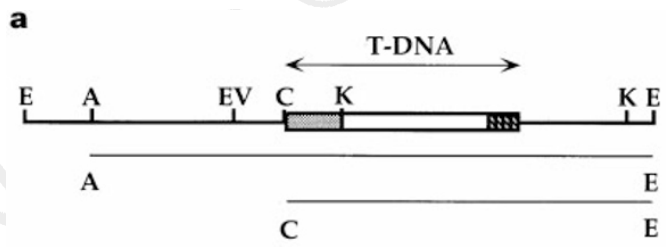

b

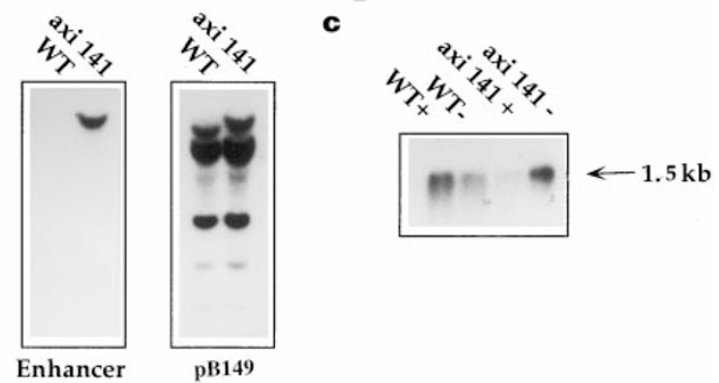

Figure 1 T-DNA organization and axi 141 expression. a, T-DNA comprises a hygromycin gene (stippled box); pIC (open box); and 35S RNA enhancers (hatched boxes) ${ }^{4}$. Restriction sites: E, EcoRl; A, Apal; EV, EcoRV; C, Clal; and K, Kpnl. The Apal-EcoRl fragment confers auxin-independent protoplast growth, but the Clal-Eco Rl fragment does not. b, EcoRl-cut genomic DNA from tobacco (WT) and axi 141 probed with the enhancer or pB149. c, Northern analysis. Total protoplast RNA from untransformed plants (WT), or axi 141 (axi 141) cultured for 3 days with (+) or without (-) auxin probed with RNA from pB149. into the cyrl is mutant $\mathrm{T} 50-3 \mathrm{~A}^{10}$. The results indicate that axi 141 functionally complements the cryl mutation in a manner similar to the cry 1 gene (Fig. 3b). Taken together, sequence similarities, raised levels of cAMP in bacteria expressing axi 141, and the functional complementation of the cryl mutation by axi 141, indicate that axi 141 probably encodes a tobacco adenylyl cyclase.
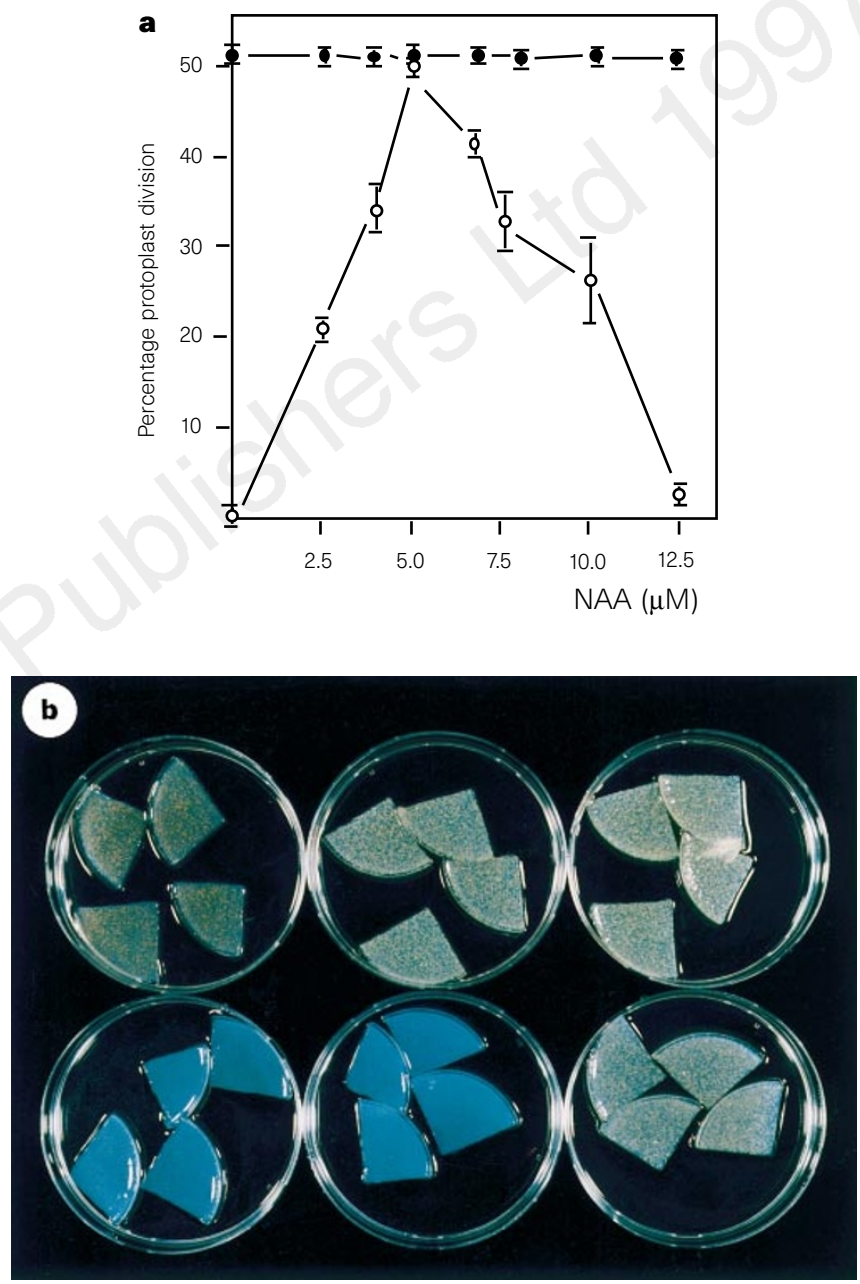

G

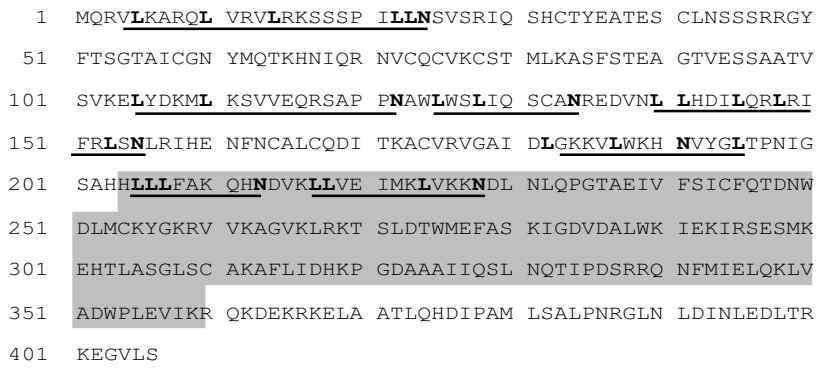

Figure 2 Functional and sequence characterizationof axi 141. a, Protoplasts from untransformed (open circles) and axi 141 plants (filled circles) cultivated under differing concentrations of auxin in the presence of cytokinin. b, Axi 141 triggers auxin-independent growth. Top row, protoplasts cultured in auxin, bottom row, protoplasts cultured without auxin. Left to right, untransfected protoplasts, protoplasts transfected with the cloning vector alone, and protoplasts transfected with pRAI14-9. c, Predicted sequence of the protein encoded by pB149. Repeats containing leucine are underlined, and the region containing greatest similarity to S. pombe adenylyl cyclase is boxed. 
The finding that deregulated expression of axi 141 results in auxin-independent growth in isolated protoplasts led us to test whether cAMP might be involved in this. Tobacco protoplasts under defined culture conditions require both auxin and cytokinin to achieve optimal frequencies of cell division ${ }^{11,12}$. Protoplasts incubated with cytokinin in the presence of the membrane-permeable dibutyryl-cAMP divide at maximal $(\sim 50 \%)$ frequency at $10 \mu \mathrm{M}$ dibutyryl-cAMP (Fig. 4a). The axi 141 protoplasts divide in the absence of auxin and are slightly more tolerant of dibutyryl-cAMP than are protoplasts from untransformed plants. In contrast, in control experiments no response was seen when protoplasts were cultured with differing levels of AMP in the presence of cytokinin. There could be two ways in which cAMP replaces auxin in triggering tobacco protoplast division: CAMP is part of either the auxin signaltransduction pathway, or a separate pathway. We adopted a pharmacological approach to differentiate between these two possibilities. Auxin-induced cell division can be inhibited by pretreating protoplasts with the anti-auxin 2-NAA ${ }^{13}$; adenylyl cyclase activity can either be inhibited by dideoxyadenosine (ddA) or stimulated by the diterpene forskolin ${ }^{14,15}$. Application of $400 \mu \mathrm{M}$ forskolin stimulated maximal protoplast division in protoplasts from untransformed plants in the absence of auxin (Fig. 4b). Stimulation of cell division by either dibutyryl-cAMP or forskolin was unaffected by pretreatment of the protoplasts with 2-NAA. However, application of ddA inhibited protoplast division in the presence of auxin. This inhibition was overcome by the addition of dibutyryl-cAMP (Fig. $4 \mathrm{~b})$. These observations confirm the idea that cAMP can replace auxin in triggering cell division in tobacco protoplasts, and that this
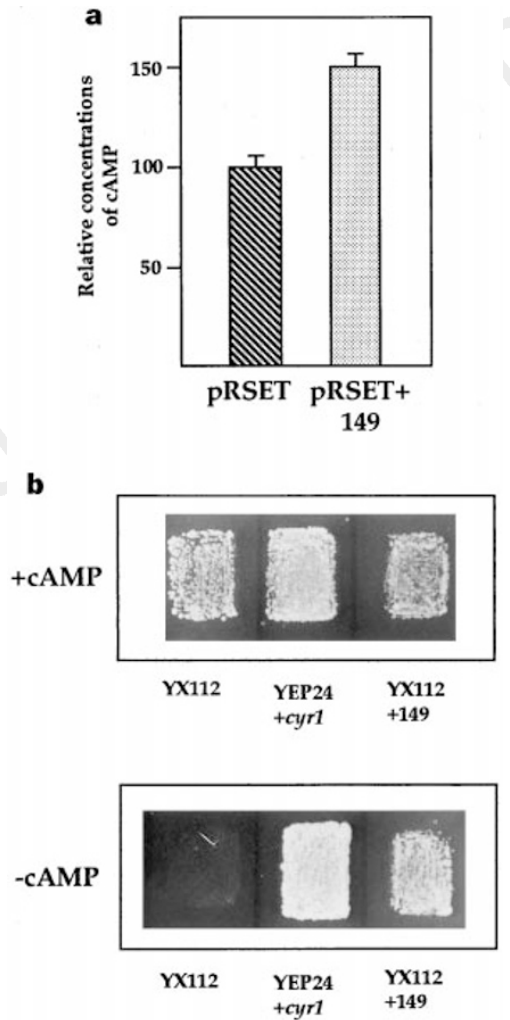

Figure 3 Functional testing of axi 141. a, Expression in E. coli. cAMP in extracts of bacteria transformed with pRSET containing no insert (pRSET), or PRSET containing the axi 141 coding region (pRSET + 149). Error bars indicate standard deviation of six independent $E$. coli transformants. Difference significant at $P=0.01$. b. Functional complementation of the yeast CRY1 mutant. Yeast cultured at $35^{\circ} \mathrm{C}$ in the absence or presence of cAMP. Left to right, T50-3A transformed with $\mathrm{pYX} 112, \mathrm{~T} 50-3 \mathrm{~A}$ transformed with $\mathrm{pYEP} 24+$ cyr1, and T50-3A transformed with $\mathrm{PYX} 112+149$. Top, with cAMP; bottom, without cAMP. is a result of adenylyl cyclase activity. That ddA inhibits auxintriggered cell division, but the inhibition is overcome by cAMP, suggests that CAMP is part of the auxin signal-transduction pathway.

Adenylyl cyclases in general are characterized by membranespanning regions, leucine-rich repeats, and the conservation of sequence at the active site located towards the $\mathrm{C}$ terminus of the gene $^{16}$. Although the structure of axi 141 is similar to that of known adenylyl cyclases, it lacks a membrane-spanning region. Size similarity of the cDNA to the signal detected on northern analysis and an inability to detect a longer transcript by $5^{\prime}$ RACE (data not shown) lead us to suspect that pB149 is not a partial cDNA. This notion is further strengthened by the finding of a 1.4-kb Arabidopsis cDNA

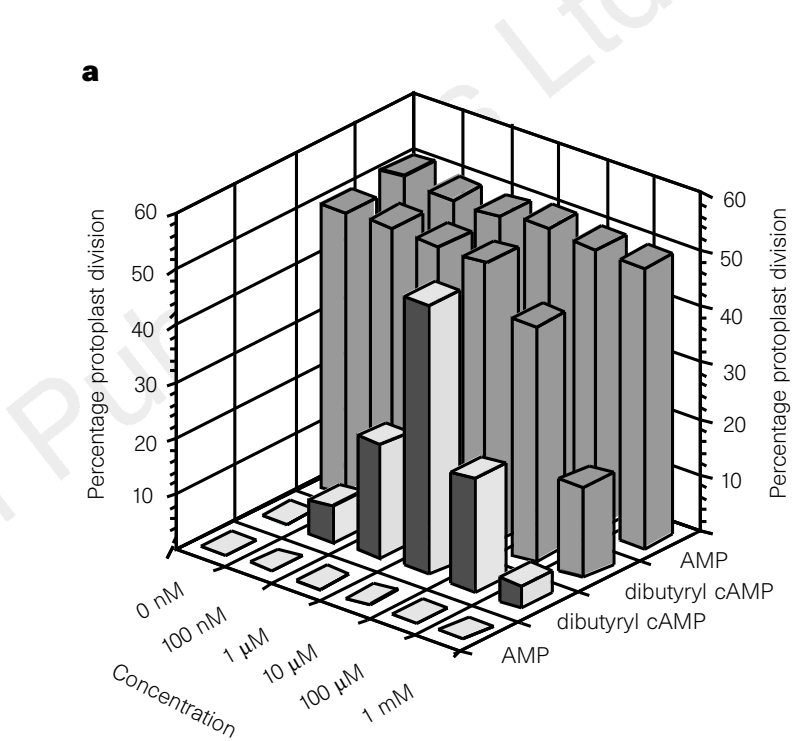

b

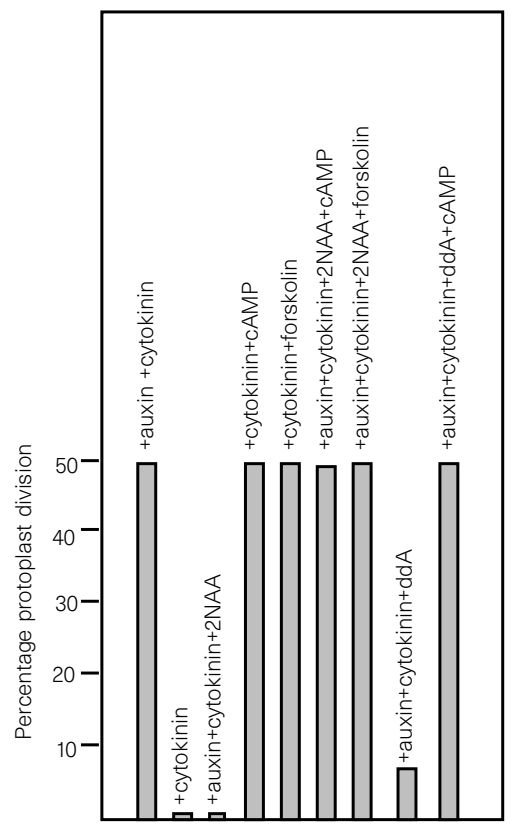

Figure 4 Effect of CAMP on protoplast division. a, Leaf protoplasts from untransformed plants (hatched columns) and from axi 141 (stippled columns) and cultured in the presence of cytokinin $(0.9 \mu \mathrm{M}$ kinetin) in increasing amounts of butyl-cAMP and AMP. Protoplast division was scored microscopically after 5 days. b. Protoplasts from untransformed tobacco plants cultivated in auxin (5.5 $\mu \mathrm{M}$ NAA), cytokinin $(0.9 \mu \mathrm{M}$ kinetin), cAMP $(10 \mu \mathrm{M})$, forskolin $(400 \mu \mathrm{M})$ and dideoxyadenosine $(100 \mu \mathrm{M})$. Protoplast division was scored microscopically after 5 days. 
with $57 \%$ identity to axi 141 (data not shown), encoded in part by an ORF located on chromosome IV of Arabidopsis (PID: g2244920), which is probably an axi 141 homologue. This ORF also lacks membrane-spanning regions, and scanning the sequence up to $15 \mathrm{~kb} 5^{\prime}$ of the ORF does not uncover an ORF containing obvious membrane-spanning regions. Thus it seems that the adenylyl cyclase is soluble. An adenylyl cyclase isolated from the plant symbiont Rhizobium is also a soluble enzyme ${ }^{17}$.

Although little is understood of the auxin signal-transduction pathway, current models hold that auxin, detected at the plasma membrane, triggers changes in ion transport as well as gene expression $^{18}$. The finding that cAMP may be involved in this is significant because, by analogy with other experimental systems, it may provide an intermediary signal capable of activating both processes. In mammals, cAMP causes changes in ion transport ${ }^{19}$ as well as in gene expression ${ }^{20}$. Indeed, cAMP has been found to stimulate $\mathrm{K}^{+}$channel activity in beans ${ }^{21}$, and several genes encoding proteins with similarities to mammalian cAMP response elementbinding protein/activating transcription factors (CREB/ATF) have been found in plants ${ }^{22}$. Generally, cAMP activates protein kinase A (PKA), which in turn initiates a phosphorylation cascade ${ }^{1}$. So far, although genes with similarities to PKA and PKC have been isolated from plants ${ }^{3}$, no plant PKA has been identified definitively. With the idea that cAMP is involved in triggering an auxin response, identification of the PKA responsible is clearly a future challenge. But our finding that a plant adenylyl cyclase is involved leads to the speculation that cAMP levels may be controlled by guanine nucleotide-binding proteins ( $G$ proteins) ${ }^{1}$. Several of these have already been identified in plants, although their exact role is yet to be established $^{23}$. The observations that higher plants have an adenylyl cyclase and that cAMP can act in auxin signalling not only provides information about auxin action, but also provides the tools and suggests strategies to isolate other components of the signal-transduction pathway leading to auxin-induced cell division.

\section{Methods}

Plant tissue culture. Activation tagging was carried out in tobacco (SR1) using pPCVICEN4HPT $^{4}$. Protoplasts from leaf tissue ${ }^{12}$ were cultured in auxin (5.5 $\mu$ M NAA; Sigma) and cytokinin ( $0.9 \mu \mathrm{M}$ kinetin; Sigma), or in cytokinin alone plus cAMP (Sigma), dibutyryl-cAMP (Sigma), forskolin (Sigma) and dideoxyadenosine (Calbiochem) at the concentrations indicated. The proportion of protoplasts undergoing division 5 days after isolation was judged microscopically using a Neubauer cell counting chamber (Fastnach) at least three times. Variation between each sample was less than $10 \%$.

Recombinant DNA techniques. Routine cloning was carried out in E. coli DH5 $\alpha$, and plasmid rescue was performed ${ }^{24}$ using E. coli DH10B (Electromax, Gibco/BRL) by electroporation as recommended by the manufacturer. A $\lambda \mathrm{gt}$ 11D (Pharmacia) cDNA library was constructed using poly $(\mathrm{A})^{+}$RNA from tobacco protoplasts 2, 3 and 5 days old cultivated in NAA (K. Fritze and H. Harling, unpublished). Positive clones were subcloned in pBluescript II SK (+) (Stratagene). Southern analysis was performed using genomic DNA from leaf tissue $e^{24}$. RNA was isolated from protoplasts with RNeasy (Qiagen). RNA probes were transcribed from pB149 (digested with XhoI) by T3 polymerase using a Riboprobe transcription kit (Promega). Expression in protoplasts was carried out using the expression vector pRT106 (ref. 25).

Measuring cAMP levels in E. coli. The EcoRI-SacI fragment of pB149, lacking 28 amino acids of the $\mathrm{N}$ terminus of axi 141, was cloned as a translational fusion with a six-histidine tag in pRSET A (Invitrogen). This was transformed into E. coli BL21(DE3)pLysS (Stratagene). Expression was induced by treatment with $\mathrm{IPTG}^{26}$. After $90 \mathrm{~min}$, cAMP was recovered using an Amprep
SAX column (Amersham) and measured by a BIOTRAK EIA kit (Amersham). Simultaneously, bacterial extracts were tested for the presence of the recombinant protein by western analysis using an anti-six-histidine-tag antibody (Qiagen).

Yeast complementation. The EcoRI-SacI fragment of pB149 was cloned into pYX112 (Ingenius) and pYX112-149 was transformed into the Saccharomyces cerevisiae CYR1 ts sensitive mutant $\mathrm{T} 50-3 \mathrm{~A}^{10}$ at the non-permissive temperature of $35^{\circ} \mathrm{C}$. Surviving clones were tested for cosegregation of the recombinant plasmid and growth under non-permissive conditions. As a control, T50-3A was transformed with either the yeast CYR1 gene ${ }^{10}$ cloned in pYEP24 (ref. 27) or pYX112 and grown at either 35 or $25^{\circ} \mathrm{C}$.

Received 19 August; accepted 26 September 1997.

1. Francis, S. H. \& Corbin, J. D. in Signal Transduction (eds Heldin, C.-H. \& Purton, M.) 223-240 (Chapman and Hall, London, 1996).

2. Trewavas, A. \& Gilroy, S. Signal transduction in plant cells. Trends Genet. 7, 356-361 (1991).

3. Assmann, S. Cyclic AMP as a second messenger in higher plants. Plant Physiol. 108, 885-889 (1995).

4. Hayashi, H., Czaja, I., Lubenow, H., Schell, J. \& Walden, R. Activation of a plant gene by T-DNA tagging: auxin-independent growth in vitro. Science 258, 1350-1353 (1992).

5. Walden, R. et al. Activation tagging: a means of isolating genes implicated as playing a role in plant growth and development. Plant Mol. Biol. 26, 1521-1528 (1994).

6. Walden, R., Hayashi, H., Lubenow, H., Czaja, I. \& Schell, J. Auxin inducibility and developmental expression of axi 1: a gene directing auxin independent growth in tobacco protoplasts. $E M B O \mathrm{~J} .13$, 4729-4736 (1994).

7. Yamawaki-Kataoka, Y., Tamaoki, T., Choe, H.-R., Tanaka, H. \& Kataoka, T. Adenylate cyclases in yeast: A comparison of the genes from Schizosaccharomyces pombe and Saccaromyces cerevisiae. Proc. Natl Acad. Sci. USA 86, 5693-5697 (1989).

8. Kroll, D. J. et al. A multifunctional prokaryotic protein expression system: overproduction, affinity purification and selective detection. DNA Cell Biol. 12, 441-453 (1993).

9. Matsumoto, K., Uno, I. \& Ishikawa, T. Identification of the structural gene and nonsense alleles for adenylate cyclase in Saccaromyces cerevisiae. J. Bacteriol. 157, 277-282 (1984).

10. Kataoka, T., Broek, D. \& Wigler, M. DNA sequence and characterisation of the S. cerevisiae gene encoding adenylate cyclase. Cell 43, 493-505 (1985).

11. Nagata, T. \& Takebe, I. Cell wall regeneration and cell division in isolated tobacco mesophyll protoplasts. Planta 92, 301-308 (1993).

12. Walden, R., Czaja, I., Schmülling, T. \& Schell, J. Rol genes alter hormonal requirements for protoplast growth and modify the expression of an auxin responsive promoter. Plant Cell Rep. 12, 551-554 (1993).

13. Röhrig, H. et al. Convergent pathways for lipochitooligosaccharide and auxin signaling in tobacco cells. Proc. Natl Acad. Sci. USA 93, 13389-13392 (1996).

14. Holgate, S. T., Lewis, R. A. \& Austen, K. F. Role of adenylate cyclase in immunologic release of mediators from rat mast cells: agonist and antagonist effects of purine- and ribose-modified adenosine analogs. Proc. Natl Acad. Sci. USA 77, 6800-6804 (1985).

15. Seamon, H. B., Padgett, W. \& Daly, J. W. Forskolin: unique diterpine activator of adenylate cyclase in membranes and intact cells. Proc. Natl Acad. Sci. USA 78, 3363-3367 (1981).

16. Taussig, R. \& Gilman, A. G. Mammalian membrane bound adenyl cyclases. J. Biol. Chem. 270, 1-4 (1995).

17. Archdeacon, J., Talty, J., Boesten, B., Danchin, A., \& O'Gara, F. Cloning of the second adenylate cyclase gene (cya2) from Rhizobium meliloti F34: sequence similarity to eukaryotic cyclases. FEMS Microbiol. Lett. 128, 177-184 (1995).

18. Macdonald, H. Auxin perception and signal transduction. Physiol. Planta 100, 423-430 (1997).

19. Hartzell, H. C., Mery, P.-F., Fishmeister, R. \& Szabo, G. Sympathetic regulation of cardiac calcium current is due exclusively to cyclic AMP-dependent phosphorylation. Nature 351, 573-576 (1991).

20. Lalli, E. \& Sassone-Corsi, P. Signal transduction and gene regulation: The nuclear response to cAMP. J. Biol. Chem. 269, 17359-17362 (1994).

21. Li, W., Luan, S., Schreiber, S. L. \& Assmann, S. M. Cyclic AMP stimulates $\mathrm{K}^{+}$channel activity in mesophyll cells of Vicia faba L. Plant Physiol. 106, 957-961 (1994).

22. Katagiri, F., Lam, E. \& Chua, N.-H. Two tobacco DNA binding proteins with homology to the nuclear factor CREB. Nature 340, 727-730 (1989)

23. Milner, P. A. \& Clausier, B. E. G-protein coupled receptors in plants cells. J. Exp. Bot. 47, 983-992 (1996).

24. Fritze, K., Czaja, I. \& Walden, R. T-DNA tagging of genes influencing polyamine metaboism: isolation of mutant plant lines and rescue of DNA promoting growth in the presence of a polyamine biosynthetic inhibitor. Plant J. 7, 101-111 (1994).

25. Töpfer, R., Maas, C., Höricke-Grandpierre, C., Schell, J. \& Steinbiss, H.-H. Expression vectors for high level gene expression in dicotyledonous and monocotyledonous plants. Methods Enzymol. 217, 66-78 (1993)

26. Studier, F. W., Rosenberg, A. H., Dunn, J. J. \& Dubendorf, J. W. Use of T7 RNA polymerase to direct expression of cloned genes. Methods Enzymol. 185, 60-89 (1990).

27. Suzuki, N. et al. Leucine rich repeats and carboxyl terminus are required for interaction of yeast adenylate cyclase with RAS proteins. Proc. Natl Acad. Sci. USA 87, 8711-8715 (1990).

Acknowledgements. We thank T. Kataoka for the yeast strain T50-3A and pYEP24-CYRI, W. Schmalenbach for technical assistance, and R. Schmidt for conversations. T.I was supported by a Alexander van Humboldt postdoctoral fellowship. C.S is supported by a DFG studentship.

Correspondence and requests for materials should be addressed to R.W. (e-mail: walden@mpiz-koeln. mpg.de). 